University of Florida Levin College of Law

UF Law Scholarship Repository

\title{
Public Law and Private Process: Toward an Organizational Justice Model of Equal Employment Quality for Caregiver
}

Rachel Arnow-Richman

University of Florida Levin College of Law, rarnowrichman@law.ufl.edu

Follow this and additional works at: https://scholarship.law.ufl.edu/facultypub

Part of the Labor and Employment Law Commons

\section{Recommended Citation}

Rachel Arnow-Richman, Public Law and Private Process: Toward an Organizational Justice Model of Equal Employment Quality for Caregiver, 2007 Utah L. Rev. 25

This Article is brought to you for free and open access by the Faculty Scholarship at UF Law Scholarship Repository. It has been accepted for inclusion in UF Law Faculty Publications by an authorized administrator of UF Law Scholarship Repository. For more information, please contact kaleita@law.ufl.edu. 


\title{
Public LaW AND PRIVATE Process: TOWARD AN INCENTIVIZED ORGANIZATIONAL JUSTICE MODEL OF EQUAL EMPLOYMENT QUALITY FOR CAREGIVERS
}

\author{
Rachel Arnow-Richman*
}

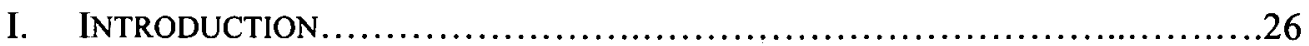

II. "SECOND-GENERATION" EXCLUSION OF WORKING CAREGIVERS:

THE STATE Of THE LAW AND THE STATE OF REFORM......................30

A. Swiss Cheese Legislation: Existing Protection for Working Caregivers......................................................... 31

B. Filling the Holes? Contemporary Models of Legal Reform......................36

C. Conclusion...........................................................44

III. The ORganizational Justice Alternative: Private

PRACTICES UNDER PUBliC SCRUTINY..........................................45

A. Judicial Adoption of Organizational Justice Principles:

Risks and Potential.................................................46

B. Organizational Justice for Caregivers: Procedural Rights

Plus Incentivized Accommodation......................................56

C. Conclusion .............................................................62

IV. THE CASE FOR PROCESS: THEORETICAL FOUNDATIONS AND

EMPIRICAL SUPPORT FOR AN ORGANIZATIONAL JUSTICE

APPROACH............................................................63

A. A "Second Generation" Response to "Second Generation"

Employment Disparities..........................................6 63

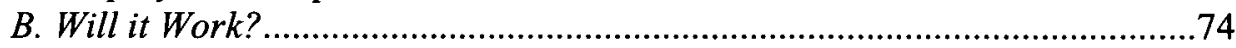

C. Conclusion ............................................................ 84

V. Questions \& CONCLUSIONS .......................................... 84

* Rachel Arnow-Richman, Assistant Professor of Law, Sturm College of Law, University of Denver. Earlier versions of this paper were presented at the April 2005 University of Denver College of Law Work in Progress Series, the March 2005 University of Utah College of Law Rolapp Visiting Scholar Lecture, and the May 2004 Annual Meeting of the Law \& Society Association. I am indebted to the many colleagues whose feedback, suggestions and support influenced the development of this article: Stephen Befort, Cynthia Estlund, Tristin Green, Seth Harris, Laura Kessler, Michael Selmi, Charles Sullivan, Michelle Travis, and the Colorado Employment Law Faculty Scholarship Network: Melissa Hart, Marty Katz, Nantiya Ruan, and Catherine Smith. Special thanks to Crystal Gordon, Patrick Rogers, Marlys Roehm and Cristel Shepherd for helpful research assistance. All errors are my own. 


\section{INTRODUCTION}

By all accounts, the problem of equal employment opportunity for nontraditional workers has morphed into a problem of equal employment quality. ${ }^{1}$ With respect to gender, women have made significant progress in accessing market work but continue to lag behind men in such areas as job advancement, pay, and consistent workforce participation. ${ }^{2}$ This type of "second-generation discrimination"-or what I prefer to think of as second-generation exclusion-has been attributed, at least in part, to women's disproportionate role in family caregiving, coupled with a combination of work norms and unconscious gender stereotypes. ${ }^{3}$ The standard way work is organized-in forty-plus-hour weeks with no time off for childrearing or elder care-excludes many caregivers ${ }^{4}$ (mostly

${ }^{1}$ See, e.g., Tristin K. Green, Discrimination in Workplace Dynamics: Toward a Structural Account of Disparate Treatment Theory, 38 HARV. C.R.-C.L. L. REV. 91, 91 (2003) ("As traditional social norms permitting overt racism and segregation give way to a modern norm of egalitarianism... discrimination often operates in the workplace today less as a blanket policy or discrete, identifiable decision to exclude than as a perpetual tug on opportunity and advancement."); Laura T. Kessler, The Attachment Gap: Employment Discrimination Law, Women's Cultural Caregiving, and the Limits of Economic and Liberal Legal Theory, 34 U. MICH. J.L. REFORM 371, 386-87 (2001) (describing an "attachment gap" in the quality of women's and men's participation in market work in terms of benefits, stability, duration, and opportunity for advancement); Susan Sturm, Second Generation Employment Discrimination: A Structural Approach, 101 ColuM. L. REV. 458, 465-69 (2001) (using the term "second generation discrimination" to refer to disparities resulting from "patterns of interaction among groups within the workplace that, over time, exclude nondominant groups" as opposed to "first generation discrimination" claims which "revolved around deliberate exclusion or subordination based on race or gender").

${ }^{2}$ Many commentators have surveyed the statistics supporting this claim and explained their relationship to women's caregiving. See, e.g., Erin L. Kelly, Discrimination Against Caregivers? Gendered Family Responsibilities, Employer Practices, and Work Rewards, in HANDBOOK OF EMPLOYMENT DISCRIMINATION RESEARCH: RIGHTS AND REALITIES 353, 355-60 (Laura Beth Nielsen \& Robert L. Nelson eds., 2005); Kessler, supra note 1, at 38586; Gillian Lester, A Defense of Paid Family Leave, 28 HARV. J.L. \& GENDER 1, 20-25 (2005).

${ }^{3}$ I consciously use the word "exclusion" rather than discrimination to separate these manifestations of inequality from the historical use of the term "discrimination" which supposed a conscious and intentional act of class-based animus. I do not disagree with other scholars who have argued convincingly that second-generation exclusion can fit within the legal definition and normative understanding of what discrimination means. See Green, supra note 1, at 99; Melissa Hart, Subjective Decisionmaking and Unconscious Discrimination, 56 ALA. L. REV. 741, 745 (2005). However, I think it important to use less pejorative terminology in order to engender support from employers and the political community.

${ }^{4}$ I will use the gender-neutral term "caregivers" throughout this Article, conscious of the fact that the limitations posed by family caregiving fall on many, if not most, women 
women, but also some men) from positions for which they are otherwise qualified. ${ }^{5}$ At the same time, lingering perceptions of the fitness of mothers for certain types of work, as well as societal expectations about fathers' role in family caregiving, may impede caregivers of both genders in competing against traditional workers. ${ }^{6}$

This Article responds to these problems with a procedural prescription. It advocates what I call an organizational justice approach to equal employment quality, consisting of a set of judicially enforceable private due process rights designed to enhance worker voice and provide incentives for voluntary employer accommodation of caregiving. In so doing, it joins the work of a number of advocates and scholars who have called for greater legal protection for working caregivers. ${ }^{7}$ These thinkers have made significant strides both in focusing the

and some, but relatively few, men. At the same time I share the views of other commentators that strategies for enabling men's increased participation in family are integral to the project of achieving equal employment quality for women. See Martin H. Malin, Fathers and Parental Leave Revisited, 19 N. ILL. U. L. REV. 25, 31-33 (1998) (arguing that lack of paternal involvement in childcare promotes discrimination against women and forces women to slow or interrupt their careers to tend to their children); Michael Selmi, Family Leave and the Gender Wage Gap, 78 N.C. L. REV. 707, 708 (2000) (" $[\mathrm{I}] \mathrm{f}$ there is to be greater equality for women in the workplace, it will be necessary for men to change their behavior, both in and out of the workplace, before employers will begin to change theirs.").

${ }^{5}$ See Joan C. Williams, Unbending Gender: Why Family and Work Conflict AND WHAT TO DO ABOUT IT 64-84, 113 (2000) (describing how market work is structured around an ideal worker who has no household or caregiving responsibilities and who receives a free flow of domestic work); Michelle A. Travis, Recapturing the Transformative Potential of Employment Discrimination Law, 62 WASH. \& LEE L. REV. 3, 11 (2005) (same).

${ }^{6}$ See Susan Huhta et al., Looking Forward and Back: Using the Pregnancy Discrimination Act and Discriminatory Gender/Pregnancy Stereotyping to Challenge Discrimination Against New Mothers, 7 EMP. RTS. \& EMP. POL'Y J. 303, 317-18 (2003); Joan C. Williams \& Nancy Segal, Beyond the Maternal Wall: Relief for Family Caregivers Who Are Discriminated Against on the Job, 26 HARV. WOMEN's L.J. 77, 94-102 (2003); Joan C. Williams, Hibbs as a Federalism Case; Hibbs as a Maternal Wall Case, 73 U. CIN. L. REV. 365, 388 (2002); infra Part II.B.1.b.

${ }^{7}$ See, e.g., WILlIAMS, supra note 5, at 243-70; Mary Becker, Care and Feminists, 17 WIS. Women's L.J. 57, 109 (2002); Marion Crain, "Where Have All the Cowboys Gone?" Marriage and Breadwinning in Postindustrial Society, 60 OHIO ST. L.J. 1877, 1932-33 (1999); Nancy E. Dowd, Work and Family: The Gender Paradox and the Limitations of Discrimination Analysis in Restructuring the Workplace, 24 HARV. C.R.-C.L. L. REV. 79, 154-55 (1989); Debbie N. Kaminer, The Work-Family Conflict: Developing a Model of Parental Accommodation in the Workplace, 54 AM. U. L. REV. 305, 333-40 (2004); Kessler, supra note 1, at 448-67; Malin, supra note 4, at 55-56; Deborah L. Rhode, Balanced Lives, 102 Colum. L. REV. 834, 846 (2002); Selmi, supra note 4, at 767-81; Katharine B. Silbaugh, Foreword: The Structures of Care Work, 76 CHI.-KENT L. REV. 1389, 1390 (2001); Peggie R. Smith, Accommodating Routine Parental Obligations in an Era of Work-Family Conflict: Lessons from Religious Accommodations, 2001 WIS. L. REV. 1443, 1491-92 (2001); Williams \& Segal, supra note 6, at 161; Joan C. Williams, 
discussion toward issues of long-term success and employment quality and in theorizing normative and doctrinal bases for holding employers responsible for the status of caregivers. To date, however, their proposals for effecting greater inclusion of working caregivers have fallen along familiar lines. Some seek mandated accommodation of workers' caregiving needs beyond the limited, unpaid leave currently available under the Family Medical Leave Act (the "FMLA"). ${ }^{8}$ Others urge expanded notions of liability and intent under Title VII's prohibition against gender and pregnancy discrimination. ${ }^{9}$ In this way, the current discussion has proceeded under an assumption, common to both accommodation and equality-based initiatives, that the problem of caregiver exclusion is one of inadequate substantive rights for working caregivers vis-à-vis their employers. ${ }^{10}$

This Article steps outside that frame of reference to offer an alternative approach, one based on organizational justice principles rather than substantive legal protections. It calls for rules that would require employers not to accommodate workers, but to establish meaningful procedures for soliciting and

Litigating the Glass Ceiling and the Maternal Wall: Using Stereotyping and Cognitive Bias Evidence to Prove Gender Discrimination, 7 EMP. RTS. \& EMP. POL'Y J. 287, 300-01 (2003).

${ }^{8}$ See, e.g., Kaminer, supra note 7, at 308; Kessler, supra note 1, at 372; Selmi, supra note 4 , at 708; Smith, supra note 7, at 1447.

9 See, e.g., WILliams, supra note 5, at 101-10 (proposing strategies for use of disparate impact and disparate treatment models to oppose workplace practices designed around male work norms); Travis, supra note 5, at 77-91 (proposing an interpretation of Title VII in which the "full-time face-time" employment norm is treated as a job practice subject to disparate impact attack); Williams, supra note 7, at 287 (offering practical guidance on how to use evidence of stereotyping and cognitive bias to bolster traditional gender-discrimination claims).

${ }^{10}$ In making this generalization, I set aside for the moment proposals that seek to reform work more generally on behalf of all employees regardless of their status, see, e.g., Vicki Schultz, Life's Work, 100 CoLUM. L. REV. 1881, 1954-56 (2000) (urging significant overhaul of the current standards of work time and compensation to allow all workers, male and female, the ability to work at a livable pace), as well as proposals that seek greater government-sponsored intervention in family caregiving or wage replacement programs financed by tax dollars, see, e.g., Rachel Arnow-Richman, Accommodation Subverted: The Future of Work/Family Initiatives in a "Me, Inc." World, 12 TEX. J. WOMEN \& L. 345, 402-09 (2003) (proposing a system of caregiver wage replacement funded through employer and employee contributions); Samuel Issacharoff \& Elyse Rosenblum, Women and the Workplace: Accommodating the Demands of Pregnancy, 94 CoLUM. L. REV. 2154, 2214-20 (1994) (proposing an insurance model under which pregnant women would be entitled to twelve weeks of post-partum benefit, a portion of which would be paid to their employers to ease dislocation costs); Lester, supra note 2, at 66-73 (proposing models of paid family leave programs); Martin H. Malin, Unemployment Compensation in a Time of Increasing Work-Family Conflicts, 29 U. MiCH. J.L. REFORM 131,133 (1996) (discussing use of unemployment insurance benefits for individuals who leave their jobs due to family obligations). See generally Katherine Elizabeth Ulrich, Insuring Family Risks: Suggestions for a National Family Policy and Wage Replacement, 14 YALE J.L. \& FEMINISM 1 (2002). 
responding to accommodation requests. This move resonates with emerging developments in other areas of discrimination law in which courts have recognized the value of procedural initiatives in achieving results under substantive mandates. Several courts interpreting the Americans with Disabilities Act (the "ADA") have held that employers must engage in an interactive process with workers to identify means of accommodating their disabilities. "In so doing, they have conferred a procedural right on workers that supplements their substantive entitlement to reasonable accommodation under the statute. Similar principles underlie the Supreme Court's jurisprudence of sexual harassment liability, under which employers who take voluntary preventative measures and meaningfully respond to victims' complaints may avoid respondeat superior liability in some instances. ${ }^{12}$ Drawing on such initiatives, this Article explores how an organizational justice approach to caregiver exclusion-one that requires good-faith consideration of proposed workplace accommodations - can facilitate the adoption of voluntary organizational changes that enhance the position of working caregivers, even in the absence of a substantive accommodation requirement.

On a broader level, this Article aspires to refine the relationship between public regulation and private behavior in achieving results-based equality for all workers. Recent employment discrimination scholarship reflects skepticism about the ability of substantive rules to eradicate lingering disparities in employment quality. ${ }^{13}$ In this vein, commentators are calling for greater interaction between employers and those seeking to reform them, recognizing that stimulating viable private solutions and a social commitment to change is critical to any enduring workplace reform agenda. ${ }^{14}$ The organizational justice approach advocated here aims to do precisely that. Given the shared interest of employers and employees in achieving mutually beneficial accommodations, the imposition of procedural obligations has the potential to achieve individually tailored solutions that may in some instances prove superior to what could be achieved under externally imposed

${ }^{11}$ See Barnett v. U.S. Air, Inc., 228 F.3d 1105, 1116 (9th Cir. 2000); Beck v. Univ. of Wis. Bd. of Regents, 75 F.3d 1130, 1135 (7th Cir. 1996); infra Part III.A.2.

${ }_{12}$ See Burlington Indus. v. Ellerth, 524 U.S. 742, 764-65 (1998); Faragher v. Boca Raton, 524 U.S. 775, 805-06 (1998); infra Part III.A.1.

${ }^{13}$ See, e.g., Linda Hamilton Kreiger, Afterword: Socio-Legal Backlash, 21 BERKELEY J. EMP. \& LAB. L. 476, 485-87 (2000) (describing the problem of judicial capture of transformative substantive rules leading to retrenchment of the status quo); Sturm, supra note 1, at 475-78 (describing the limits of fixed commands in redressing second-generation discrimination problems that defy clear rules and boundaries).

${ }^{14}$ See, e.g., Kreiger, supra note 13, at 498-503 (describing how interaction with the community regulated by an appearance-discrimination ordinance helped ensure greater success in ultimate enforcement); Sturm, supra note 1, at 566 (suggesting a need for greater attention to the role of mediating institutions, employee organizations, and other private actors in successful elimination of "second generation" discrimination); cf. Cynthia Estlund, Rebuilding the Law of the Workplace in an Era of Self-Regulation, 105 CoLUM. L. REV. 319, 378-83 (2005) (proposing a model of monitored self regulation for enforcing labor standards). 
substantive mandates. Under this approach, process supplies an alternative touchstone for evaluating employer conduct, one that bridges the theoretical gap between liability and intent.

This Article proceeds as follows: Part II provides an overview of the problem of caregiver exclusion. It describes the joint problems of structural exclusion and cognitive bias and examines two sets of responses by legal scholars. ${ }^{15}$ Part III explores the potential for an alternative, private account of caregiver exclusion. It highlights three principle features of an organizational justice approach to caregiver exclusion: an emphasis on internal employer practices as opposed to external legal standards; the use of incentivizing penalties and presumptions in addition to substantive rule-based requirements; and a focus on efforts to correct disparities in employment quality rather than intent to discriminate in assessing employer liability. ${ }^{16}$ Part III then develops a prescription for incorporating procedural rights and accompanying incentives in existing laws that protect caregivers. It proposes an amendment to the FMLA that would confer procedural rights on qualified workers and a shift in burdens of proof in favor of discrimination plaintiffs whose employers fail to engage in good-faith consideration of accommodation requests. ${ }^{17}$ Part IV tests the approach laid out in Part III. It lays a theoretical basis for an organizational justice approach by situating these recommendations within the context of increased attention to private procedures and practices in discrimination scholarship and regulatory theory generally. ${ }^{18}$ It then contemplates how the prescription is likely to fare in practice, drawing on a comparable initiative under British law and social science research on the value of procedural justice. ${ }^{19}$ This Article concludes that while organizational justice is not a panacea, it has the potential to achieve meaningful solutions for at least some working caregivers and can ideally serve as a model for more inclusive workplace practices that will benefit all workers.

\section{II. "SECOND-GENERATION" EXCLUSION OF WORKING CAREGIVERS: THE STATE OF THE LAW AND THE STATE OF REFORM}

There are currently two sources of federal protection for working caregivers: the Pregnancy Discrimination Act and the FMLA, neither of which is equipped to fully address disparities in employment quality. This section briefly identifies the key features of these laws and their limitations, and summarizes the primary legal reform strategies for enhancing current caregiver law. Such efforts principally target two overlapping categories of employer behavior and their effects on workers: (1) structural exclusion-the recognition that the design and organization of work incorporate the sensibilities and preferences of white, male decision

\footnotetext{
${ }^{15}$ See infra Parts II.A, II.B.1-2.

${ }^{16}$ See infra Part III.A.1-2.

${ }^{17}$ See infra Part III.B.1-2.

${ }^{18}$ See infra Part IV.A.1-5.

${ }^{19}$ See infra Part IV.B.1-2.
} 
makers, ${ }^{20}$ and (2) cognitive bias-the discovery that individual exercises of discretion are affected by unconscious cognitive shortcuts in ways that reflect social biases. ${ }^{21}$

\section{A. Swiss Cheese Legislation: Existing Protection for Working Caregivers}

Existing federal protection for working caregivers consists of a prohibition against irrational discrimination based on pregnancy and modest unpaid leave for childbirth, adoption, or the serious illness of a family member. Under the Pregnancy Discrimination Act, an employer may not treat a pregnant worker differently than other workers who are similarly situated in their ability to perform the requirements of their job. ${ }^{22}$ In other words, if the employer provides benefits or accommodations to non-pregnant disabled workers, it must do so for pregnant workers as well. ${ }^{23}$ Of course, the employer is free to distinguish between pregnant

${ }^{20}$ See generally Dowd, supra note 7, at 136 ("[T] cause work-family conflict are largely structural features that have resulted from the adoption of facially neutral policies, or from the inaction and inadequacies of the structure which generate conflict between work-family roles."); Green, supra note 1, at 92-95 (describing modern discrimination as facilitated by group dynamics, organizational structure, and institutional practices); Sturm, supra note 1, at 468-70 (suggesting that overt discrimination "operates in tandem with or is supplanted by subtle, interactive, and structural bias"). Cf. Michael A. Rebell, Structural Discrimination and the Rights of the Disabled, 74 GEO. L.J. 1435, 1452 (1986) ("[T]he critical analytical problem of discrimination in the handicapped context now is less one of overcoming bigotry and invidious prejudice than one of redesigning social structures and institutions to make them more responsive to the needs of the disabled segment of the population. It is, in short, a problem of structural change."); see infra Part II.B.1.a.

${ }^{21}$ See generally Linda Hamilton Krieger, The Content of Our Categories: A Cognitive Bias Approach to Discrimination and Equal Employment Opportunity, 47 STAN. L. REV. 1161,1187 (1995) (discussing the theory of social cognition that describes how cognitive structures and processes involved in categorization and information processing often result in stereotyping); Amy L. Wax, Discrimination as Accident, 74 IND. L.J. 1129, 1131 (1999) (characterizing "inadvertent bias" as the result of decision makers' reliance on "reflexive or unthinking distortions in the application of neutral and seemingly reasonable criteria to the assessment of employees from disfavored groups"); Williams \& Segal, supra note 6, at 94101 (describing how prescriptive and benevolent stereotyping affect employers' perceptions and evaluation of pregnant workers and workers returning from maternity leave). See infra Part II.B.1.b.

${ }^{22}$ The PDA is an amendment to Title VII which provides that discrimination on the basis of "sex" includes discrimination on the basis of pregnancy. See 42 U.S.C. $\S 2000 \mathrm{e}(\mathrm{k})$ (2006).

${ }^{23}$ See, e.g., Deneen v. Nw. Airlines, Inc., 132 F.3d 431, 437 (8th Cir. 1998) (finding that an occupational qualification that an airline customer service agent must be able to lift luggage of up to seventy-five pounds applied to a pregnant employee but not other employees could be viewed by a reasonable jury as discriminatory); Byrd v. Lakeshore Hosp., 30 F.3d 1380, 1383-84 (11 th Cir. 1994) (finding discrimination where pregnant employee who took sick leave was terminated while other temporarily disabled or sick 
and non-pregnant workers on legitimate business grounds, or simply to treat all workers "equally badly."24 Under the FMLA, an employee of either gender ${ }^{25}$ is entitled to a maximum of twelve weeks of unpaid, job-protected leave for a discrete set of qualifying caregiving-related events. ${ }^{26}$ These events include birth or adoption, serious health condition of a family member, and medical conditions related to pregnancy. ${ }^{27}$ However, benefits are limited to unpaid leave, the continuation of medical insurance, and the right to job reinstatement. ${ }^{28}$ The employer need not provide anything further to an employee who requires additional time off beyond the twelve-week period or some lesser form of accommodation. ${ }^{29}$

To illustrate the limitations of these laws, consider the following:

Illustration 1: A pregnant woman is employed as a delivery truck driver. Part of her job involves lifting and loading inventory. Due to complications with her pregnancy, her physician advises her not to lift objects in excess of fifteen pounds. In the past the employer has authorized short-term lifting restrictions for employees suffering from a temporary disability. She requests such a restriction, and is denied. ${ }^{30}$

employees in similar positions were not); United States v. Bd. of Educ., 983 F.2d 790, 798-99 (7th Cir. 1993) (holding that the employer's maternity leave policy was discriminatory because it prohibited pregnant teachers from combining paid sick leave with unpaid maternity leave but allowed non-pregnant sick teachers to combine sick leave with other forms of unpaid leave).

${ }^{24}$ Troupe v. May Dep't Stores Co., 20 F.3d 734, 738 (7th Cir. 1994); see also Stout v. Baxter Healthcare Corp., 282 F.3d 856, 860 (5th Cir. 2002) (finding no unlawful discrimination because "[a]lthough [employer]'s policy results in the dismissal of any pregnant or post-partum employee who misses more than three days of work during the probationary period, it equally requires the termination of any non-pregnant employee who misses more than three days"); Gorman v. Wells Mfg. Corp., 209 F. Supp. 2d 970, 980 (S.D. Iowa 2002) (finding against pregnant employee fired for absenteeism related to her pregnancy because she "failed to meet her burden to produce any evidence that similarly situated non-protected class employees were treated more favorably than she").

${ }^{25}$ See 29 U.S.C. § 2611(2); 29 C.F.R. § 825.112(b) (2006).

${ }^{26}$ See 29 U.S.C. $\$ 2612(\mathrm{a})(1) ; 29$ C.F.R. $\$ 825.112(\mathrm{a})$.

${ }^{27}$ See 29 U.S.C. $\S 2612(\mathrm{a})(1)(\mathrm{A})-(\mathrm{D}) ; 29$ C.F.R. $\$ \S 825.100(\mathrm{a}), 825.112(\mathrm{a})$, (c). FMLA leave is also available for serious health conditions of the employee other than pregnancy. Because this Article deals with the needs of working caregivers, however, I focus here on how the FMLA protects those who require leave as a result of a new child or to care for others.

${ }^{28}$ See 29 U.S.C. $\S \S 2612$ (c)-(d), $2614(\mathrm{a})$, (c); 29 C.F.R. § 825.200(a)-(c).

${ }^{29}$ Both the FMLA and the PDA have been widely criticized on these grounds. See, e.g., Williams, supra note 5, at 112, 229, 237; Kessler, supra note 1, at 374-76; Selmi, supra note 4 , at 711 .

${ }^{30}$ This illustration is based on Walker v. Fred Nesbit Distributing Co., 356 F. Supp. 2d 964, 965-66 (S.D. Iowa 2005). 
In this scenario, the employee has limited rights under the PDA and the FMLA. Under the PDA she is entitled to the lifting restriction only if the employer makes that accommodation for other disabled workers. If so, by denying the restriction, the employer is arguably discriminating against her based on pregnancy. However, the employer may interpose a valid reason for the distinction, arguing, for instance, that past lifting restrictions were provided only to workers injured on the job and not for non-work-related disabilities. ${ }^{31}$ If this distinction has a legitimate financial basis, the PDA claim will be unavailing. ${ }^{32}$ Fortunately, this employee is entitled to benefits under the FMLA. Because her medical condition is related to pregnancy, it constitutes a "serious health condition" of the employee, which is considered a qualifying event. ${ }^{33}$ However, the only benefit she can demand is unpaid leave, meaning she will be forced to stop working entirely and lose her salary. ${ }^{34}$ The FMLA does not give her the ability to insist on the lesser accommodation of a lifting restriction. Also, she is limited to twelve weeks. ${ }^{35}$

${ }^{31}$ See, e.g., Spivey v. Beverly Enters., Inc., 196 F.3d 1309, 1313 (11th Cir. 1999) (finding no discrimination in failure to grant lifting restriction to pregnant employee where employer's policy provided modified-duty accommodations only to employees suffering occupational injuries); Urbano v. Cont'l Airlines, Inc., 138 F.3d 204, 206 (5th Cir. 1998) (same); Walker, 356 F. Supp. $2 \mathrm{~d}$ at 969 (same).

${ }^{32}$ In this way, pregnancy claims follow the same burden of proof structure associated with other disparate treatment claims: the employer prevails if the jury believes its decision was motivated exclusively by a legitimate non-discriminatory reason, see St. Mary's Honor Ctr. v. Hicks, 509 U.S. 502, 506-07 (1993); Tex. Dep't of Cmty. Affairs v. Burdine, 450 U.S. 248, 254-55 (1981); McDonnell Douglas Corp. v. Green, 411 U.S. 792, 802 (1973), or that its decision was motivated by discriminatory and non-discriminatory reasons, the latter being sufficient to motivate the adverse decision, see Desert Palace, Inc. v. Costa, 539 U.S. 90, 93-94 (2003); Price Waterhouse v. Hopkins, 490 U.S. 228, 241-42 (1989). In the mixed-motive situation, according to the Civil Rights Act of 1991, the employer is technically still in violation of Title VII because it took account of the employee's protected status in its deliberations, but its liability is only nominal; the plaintiff is not entitled to a damage award. Civil Rights Act of $1991 \S 107,42$ U.S.C. $\S 2000 \mathrm{e}-5(\mathrm{~g})$.

33 Under the FMLA, a "serious health condition" means an illness, injury, impairment, or physical or mental condition that involves inpatient care in a hospital, hospice, or residential medical care facility; or continuing treatment by a health care provider. 29 U.S.C. $\S 2611$ (11); see also 29 C.F.R. § 825.114(a).

${ }^{34}$ As many have noted, the absence of any compensation requirement makes FMLA leave time of limited use to many workers. See, e.g., Donna Lenhoff \& Claudia Withers, Impelemenation of the Family and Medical Leave Act: Toward the Family-Friendly Workplace, 3 AMER. U. J. OF GENDER \& L. 39, 53 (1994) ("To make the right to family and medical leave a meaningful one to all workers, policymakers must devise a method to provide workers with paid family and medical leave."); Rhode, supra note 7, at 845 ("Only about seven percent of those eligible for FMLA leaves actually take them, generally because they cannot afford to do so."); Jane Rigler, Analysis and Understanding of the Family and Medical Leave Act of 1993, 45 CASE W. RES. L. REV. 457, 479 (1995) ("For those poorly paid employees who have no (or limited use of) paid vacation, sick leave or family leave, the FMLA may simply be irrelevant.").

${ }^{35} 29$ U.S.C. $\S 2612(a)(1) ; 29$ C.F.R. § 825.200(a). 
Thus, if her lifting limitation endures for the full term of her pregnancy and she remains off work, she will lose her right to job reinstatement. ${ }^{36}$ In addition, by using up the full twelve weeks of leave during her pregnancy, the employee will have no FMLA leave time to care for her newborn following childbirth. ${ }^{37}$

Illustration 2: An in-house attorney adopts a healthy child. She takes twelve weeks of unpaid leave under the FMLA and returns from leave full-time. After a few months, she realizes she is unable to meet the demands of her job and adequately care for her child. She asks to work a four-day week (a male administrative assistant currently has that work arrangement), but her supervisor denies the request because "all of the attorneys in the office work full-time." One year later she is laid off in a legitimate reduction in force. She is selected based on her relatively high absence record and light caseload compared to other attorneys in the office.

In this scenario, the employee has no protection under either statute. Because she is not and was not pregnant, she is not within the class of persons protected under the PDA. In theory, she could allege discriminatory failure to accommodate under Title VII, arguing that she was unfairly treated vis-à-vis the male employee who was permitted to work part-time ${ }^{38}$ However, as with the truck driver's PDA claim, success turns on the presence of appropriate comparators and, in this scenario, the facts suggest the male employee, who holds a significantly different position, is not similarly situated. ${ }^{39}$ As for the subsequent layoff, if the employer's

${ }^{36}$ See, e.g., Hicks v. Leroy's Jewelers, Inc., No. 98-6596, 2000 WL 1033029, at *3 (6th Cir. July 17, 2000) (finding no FMLA violation in employer's decision to terminate employee who failed to return to work after the twelve-week leave period due to complications during childbirth); Grosenick v. SmithKline Beecham Corp., No. 03-CV2607, 2005 WL 1719117, at*4-5 (D. Minn. July 22, 2005) (finding no FMLA violation where employer replaced an employee after the twelve-week leave period because it never received notice from the employee's doctor indicating that the employee could come back to work).

${ }^{37}$ See 29 U.S.C. $\S 2612(a)(1)$ (entitling an employee to twelve work weeks of leave during any twelve-month period for qualified reasons); 29 C.F.R. § 825.200(a) (limiting an eligible employee's FMLA leave entitlement to twelve weeks of leave during any twelvemonth period). Cf. 29 C.F.R. $\S 825.214$ (b) ("If the employee is unable to perform an essential function of the position because of a physical or mental condition, including the continuation of a serious health condition, the employee has no right to restoration to another position under the FMLA."). .

${ }^{38}$ See, e.g., Orr v. Albuquerque, 417 F.3d 1144, 1152 (10th Cir. 2005) (finding prima facie case of pregnancy discrimination where employer allowed some male workers to use compensatory time for FMLA leave, but forced plaintiffs to use accrued sick leave for FMLA leave following childbirth).

${ }^{39}$ See, e.g., Spivey v. Beverly Enters., Inc., 196 F.3d 1309, 1313 (11th Cir. 1999) (finding for purposes of discriminatory failure to accommodate claim that "correct comparison is between Appellant and other employees who suffer non-occupational 
explanation for its selection is true, the termination is lawful. Because the employee is past the qualifying event of child birth, and assuming her absences are attributable to the ordinary demands of parenting (rather than a serious health condition of her child), the FMLA is inapplicable. ${ }^{40}$

Illustration 3: Same facts as Illustration 2, above, except the employee is a male computer programmer and he requests part-time work to care for an ill parent rather than a child.

Here the employee is in a slightly better position. If the parent's illness qualifies as a serious health condition, the programmer will qualify for FMLA leave and may be able to take the leave on an intermittent basis approximating part-time employment. ${ }^{41}$ If the employer fails to oblige, the programmer can bring a claim for interference with FMLA rights. ${ }^{42}$ His entitlement to intermittent leave, however, is in lieu of full-time leave. If he chooses to use the twelve weeks upon the immediate onset of the illness, like the attorney in Illustration 2 who takes fulltime leave upon the adoption, he too will have no further accommodation or leave rights to deal with ongoing caregiving demands. The programmer is also in a better position in the event of a future layoff. If his part-time leave is FMLA-eligible, the employer may not use it as a basis for an adverse employment decision. ${ }^{43}$ That protection ends, however, when the qualified leave ends. In other words, if his attendance declines or his work suffers after returning to full-time status, the employer would have a legitimate non-discriminatory reason for terminating him that would likely defeat a subsequent retaliation claim.

Thus, the PDA and the FMLA each are a partial solution to caregiver exclusion. While the PDA protects pregnant workers from some forms of differential treatment, it does so only in situations where the pregnant employee is not limited in her ability to perform or where comparably limited non-pregnant

disabilities, not between Appellant and employees who are injured on the job "); Urbano v. Cont'1 Airlines, Inc., 138 F.3d 204, 208 (5th Cir. 1998) (finding that "Continental treated Urbano the same as it treats any other worker who suffered an injury off duty. There is no probative evidence that Continental's distinction between occupational and off-the-job injuries was a pretext for discrimination against pregnant women.”)

${ }^{40}$ See 29 C.F.R. $§ 825.114$ ("Ordinarily, unless complications arise, the common cold, the flu, earaches, upset stomach . . . are examples of conditions that do not meet the definition of a serious health condition and do not qualify for FMLA leave.").

${ }^{41}$ Intermittent leave is an entitlement only for those who need such leave as a result of a qualifying medical condition of the employee or his or her family member. See 29 C.F.R. $\S 825.203(\mathrm{c})(2)$. Intermittent leave for a new child is at the discretion of the employer. See id. $\S 825.203(\mathrm{~b})$.

${ }^{42}$ See 29 U.S.C. $\S 2615$ (a); 29 C.F.R. $\$ 825.220$.

${ }^{43}$ Recent cases also suggest that "mixed motive" analysis would apply to this claim. Thus the employee's qualified absences need only be a motivating factor in the layoff decision, and not the sole cause, for a finding of discrimination. See Richardson v. Monitronics Int'l, Inc., 434 F.3d 327, 334-35 (5th Cir. 2005) (applying Desert Palace in FMLA case); supra note 32 . 
employees are more favorably treated. It mandates no accommodation of pregnant employees and is completely silent on issues of caregiver exclusion that occur after pregnancy. The FMLA does mandate some accommodation of the real effects of caregiving, but it does so only in the context of critical life events-birth or serious illness-ignoring the constraints imposed by the everyday demands of caregiving. In addition, its mandate is inflexible. The only type of accommodation that an employer must provide is a fixed amount of unpaid leave; an employee who desires more or less flexibility is without recourse.

\section{B. Filling the Holes? Contemporary Models of Legal Reform}

Scholars and advocates have responded to these limitations with a variety of proposals for expanded employment discrimination and family leave protection that better address the needs of caregivers. Their proposals fall largely in one of two related categories. The first, which I call the "expanded intent" model, aims to reinterpret existing non-discrimination directives to embrace employer conduct and workplace structures that may be subtly tied to bias or perpetuate biased effects, but which are not routed in group-based animus. The second, which I refer to as the "mandated benefit" model, aims to legislate additional employer-provided benefits for caregivers and greater accommodation of their job-related limitations. Both models provide theoretical foundations for enhancing the rights of caregivers and are likely to provide additional legal protection to some plaintiffs; however, neither offers a unifying theory for pursuing legal change, nor can they address the range of situations that compromise caregivers' employment quality. This subsection briefly explains the two models and their limitations.

\section{The Expanded Intent Approach: Caregiver Exclusion as Gender or Pregnancy Discrimination}

To the extent existing laws have traditionally conceived of discrimination as intentional behavior predicated on group-based animus, they may be ill-equipped to respond to employer behavior and workplace structures that are either benign in intent or entirely unintentional. ${ }^{44}$ In light of this, an initial aim of secondgeneration scholarship has been to reinterpret existing anti-discrimination laws in ways that hold employers accountable for employment quality disparities regardless of their source. This has been achieved principally by arguing for an expanded notion of intent that better reflects the way second-generation exclusion manifests in the contemporary workplace.

${ }^{44}$ See generally Green, supra note 1, at 91; Kreiger, supra note 13 , at 485 . But see Hart, supra note 3, at 766 (suggesting that scholars have overstated the problem of addressing unconscious discrimination through existing law and that Title VII, properly understood and applied, is up to the task of uprooting such behavior); Michael Selmi, Was the Disparate Impact Theory a Mistake?, 53 UCLA L. REV. 701, 744-46 (2006) (suggesting that instances of biased application of subjective employment standards can appropriately be framed as intentional disparate treatment claims). 


\section{(a) Challenging Work Structures}

Some scholars suggest that structural exclusion of women caregivers may be attacked through formal equality rules by rigorously analyzing existing work requirements and their justifications. ${ }^{45}$ Most jobs are designed with the expectation that workers can perform forty hours or more per week and will take little or no time off for childbearing or rearing during the course of their career. ${ }^{46}$ While that design was not selected out of animus or a desire to exclude, it tends to disadvantage workers who do not conform to this ideal worker norm. Thus, pregnant women and women with children may find it difficult to break into the labor market, while those who are employed may find themselves passed over for promotions and plum assignments, particularly in jobs that demand frequent travel and overtime ${ }^{47}$ In situations such as these, where employers' "legitimate" demands exclude or disadvantage caregivers, courts should deconstruct the justifications for those requirements and consider alternative ways for employers to package and evaluate work. ${ }^{48}$

In application, this theory addresses some of the gaps in existing law identified in the previous section. It might, for instance, allow the truck driver in Illustration 1 to challenge the employer's bundling of job functions (lifting and driving) as a discriminatory job practice that disparately impacts pregnant women. Similarly, it could enable the lawyer in Illustration 2 to challenge the hours and structure of her job (full-time/full-week) as disparately impacting women, who serve as the primary caregivers in most families. Both plaintiffs could argue that their employer's failure to alter work structures and practices in the face of exclusionary effects constitutes a form of unlawful gender discrimination.

Certainly there is some precedent to suggest potential for cases like this, ${ }^{49}$ but, as a practical matter, the approach is likely to have only minimal effect. Despite the codification of disparate impact jurisprudence in the 1991 Civil Rights Act

${ }^{45}$ See WILLIAMS, supra note 5, at 101-10.

${ }^{46}$ See id. at 1; Kessler, supra note 1, at 374-75 (describing ideal workers as providing a full-time, uninterrupted stream of market work); Travis, supra note 5 , at 6 (describing a "full-time face-time" norm that requires "full-time positions, unlimited hours, rigid work schedules, an uninterrupted work life, and performance of work at a central location").

${ }^{47}$ See WILLIAMS, supra note 5, at 71-76 (discussing the creation of a marginalized "mommy track" for caregivers within professional firms and the ab initio exclusion of women from most blue-collar jobs); Williams \& Segal, supra note 6, at $95 \mathrm{n} .118$ (describing how employers pass over caregivers for positions requiring frequent travel).

${ }^{48}$ See Williams \& Segal, supra note 6, at 109 (arguing that the ability to work in an environment defined by and structured around male bodies and norms cannot be a legitimate job qualification).

${ }^{49}$ See, e.g., EEOC v. Warshawsky \& Co., 768 F. Supp. 647, 654-55 (N.D. Ill. 1991) (finding the employer's policy of terminating any first-year employee requiring long-term sick leave disparately impacted women who could become pregnant despite the employer's assertion that the policy reduced turnover). 
Amendments, successful "unintentional" discrimination cases have been rare. ${ }^{50}$ Existing law permits employers to avoid liability for exclusionary effects where a challenged job practice is supported by a legitimate business decision. ${ }^{51}$ That defense has been broadly construed to include not only decisions based on cost, but other acts of managerial discretion not intended-in the traditional sense of the word-to exclude. ${ }^{52}$ In addition, courts have taken a narrow view of what it means to demonstrate a "job practice" that creates a disparate effect, refusing to treat workplace norms as practices. ${ }^{53}$ For these reasons, it is unlikely courts will accept the underlying idea that an employer's failure to alter its work practices in light of disparities in the employment quality of caregivers is equivalent to gender discrimination absent some further elaboration by Congress. ${ }^{54}$

Moreover, even if courts were willing to embrace this liability theory it would do nothing to ameliorate the male computer programmer's situation in Illustration 3 if his parent's illness is not FMLA-eligible or if he exhausts his leave entitlement. An expansive reading of disparate-impact law is premised on the notion that women, as the primary caregivers in most families, are disproportionately harmed relative to men by traditional work structures. As long as this gendered division of labor persists, men will not be able to take advantage of the theory because they will not be able to show the requisite disparate impact on the basis of sex. Thus, if mainstreaming male caregiving practices is a real goal of the work/family balance movement, other long-term strategies will be needed.

${ }^{50}$ See Selmi, Disparate Impact Theory, supra note 44 at $738-43$ (reporting limited success rate of plaintiffs in empirical study of disparate impact cases).

${ }^{51}$ See 42 U.S.C. $\$ 2000 \mathrm{e}-2(\mathrm{k})(1)(\mathrm{A})(\mathrm{i})(2006)$ (providing that a plaintiff establishes a disparate statistical impact where "the respondent fails to demonstrate that the challenged practice is job related for the position in question and consistent with business necessity").

${ }^{52}$ See, e.g., Personnel Adm'r of Mass. v. Feeney, 442 U.S. 256, 265 (1979) (finding no disparate impact in the state's use of preference in hiring veterans as the practice was "justified as a measure designed to reward veterans for the sacrifice of military service, to ease the transition from military to civilian life, to encourage patriotic service, and to attract loyal and well-disciplined people to civil service occupations"); Chambers v. Omaha Girls Club, 629 F. Supp. 925, 951 (D. Neb. 1986) (finding no actionable disparate impact in the employer's practice of terminating single pregnant women where the practice furthered its goal of "fostering growth and maturity of young girls"). But see Christine Jolls, Commentary: Antidiscrimination and Accommodation, 115 HARV. L. REV. 642, 653-63 (2001) (summarizing other disparate impact cases in which courts have held employers liable despite the presence of a legitimate business rationale for the challenged job practice).

${ }^{53}$ See Travis, supra note 5, at 39-46.

${ }^{54}$ See Kathryn Abrams, Cross-Dressing in the Master's Clothes, 109 YALE L.J. 745, 754-61 (2000) (reviewing WILLIAMS, supra note 5, and questioning practical viability of her proposals); Selmi, Disparate Impact Theory, supra note 44 at $750-51$ (suggesting that although many common employer policies "almost certainly have a disparate impact [on pregnant women or women with childrearing responsibilities], they are also subject to an employer's business rationale, and few courts appear willing to undo standard business practices without a far stronger statutory mandate"). 


\section{(b) Capturing Cognitive Bias}

Another avenue for expanding the concept of intent draws on the scientific understanding of cognitive bias. Psychological research teaches that identifying and accounting for human differences is part of the natural cognition process through which the brain categorizes information in order to manage it efficiently. ${ }^{55}$ The brain represents these cognitive categories through a mental image, or schema, which operates both as a prototype for that category and as a set of predictions about what we perceive. ${ }^{56}$

In the workplace, cognitive bias can result in both stereotyping and in-group favoritism, which may prevent employers from fairly evaluating the qualifications or performance of non-traditional employees, including caregivers. ${ }^{57}$ In the case of pregnancy, the physical appearance of a pregnant worker tends to exacerbate gender stereotypes about the appropriate role of women. ${ }^{58}$ Thus, employers may regard pregnant employees as too soft or subdued for an important position or assignment; or, in the case of a pregnant worker who is assertive, inappropriately aggressive or pushy. ${ }^{59}$ Similarly, childbearing and motherhood are associated with a loss of competence, dependability, and commitment to the job, perceptions that endure past the conclusion of pregnancy. ${ }^{60}$ Importantly, such biases affect not only

${ }^{55}$ See Krieger, supra note 21, at 1188-89 ("“Since no organism can cope with infinite diversity, one of the most basic functions of all organisms is the cutting up of the environment into classifications by which nonidentical stimuli can be treated as equivalent." (quoting Eleanor Rosch, Human Categorization, in STUDIES IN CROSSCultural Psychology 1, 1-2 (Neil Warren ed., 1977))).

${ }^{56}$ See id. at 1190 (discussing the theory of social cognition that describes how cognitive structures and processes involved in categorization and information processing often result in stereotyping); Wax, supra note 21 , at 1131 (characterizing "inadvertent bias" as the result of decision makers' reliance on "reflexive or unthinking distortions in the application of neutral and seemingly reasonable criteria to the assessment of employees from disfavored groups").

${ }^{57}$ See Krieger, supra note 21, at 1206 (noting that where both male and female employees perform a stereotypically male task poorly, the female may be more severely punished because the supervisor sees her performance as "dispositional" and sees the male's performance as "situational"); Williams, supra note 7, at 294 (describing "the tendency of in-groups to apply objective rules rigorously to outsiders but flexibly to insiders").

${ }^{58}$ See Huhta et al., supra note 6 , at 318 .

${ }^{59}$ See id. at 18 (describing how stereotypes place a pregnant woman in a double bind in that "she can conform to a feminine script and be judged to "lack drive" and competence; or she can continue to be hard-driving and be judged to have personality problems"); Williams, supra note 6, at 388 (citing a study that found performance reviews of pregnant managers plummeted due to stereotypes of women as irrational and overly emotional).

${ }^{60}$ See Huhta et al., supra note 6, at 318-20 (summarizing studies demonstrating that working mothers received competence ratings equivalent to those of elderly, retarded, and 
particular personnel decisions, but the everyday assessment of workers that forms the basis for later action. Thus, a supervisor may notice the errors or absences of a working mother, but not those of a working father, and as a consequence develop an unjustifiably critical view of the mother relative to her coworkers. ${ }^{61}$

In response to such research, scholars have proposed disaggregating intent and causation to accommodate the fact that disparate treatment can result absent a conscious discriminatory purpose. ${ }^{62}$ As long as a decision is "actuated" by bias, liability should attach, entitling the worker to the equitable remedies available to successful disparate impact plaintiffs. ${ }^{63}$ Thus, an employer would be liable where stray comments and other circumstantial evidence suggest an employer's decision was influenced by the belief that mothers are not committed to their jobs and should stay at home with their children. ${ }^{64}$ Similarly, an employer would be liable where an employment action is based on performance judgments that reflect unjustified assumptions about a caregiver's competence, as, for instance, where written evaluations show unprecedented negative evaluations following pregnancy or childbirth. ${ }^{65}$ Under this theory, such decisions would be treated as discriminatory despite the subconscious nature of the bias.

The cognitive bias approach is likely to prove fruitful in a subset of cases in which employer decisions appear suspect. Indeed, the Supreme Court recently approved an interpretation of causation that is likely to expand situations where juries can find liability on the basis of a mixed motive. ${ }^{66}$ Under Desert Palace $v$. Costa, a plaintiff demonstrates discrimination where she shows, by any evidence, that consideration of impermissible characteristics played at least a part in the employer's decision. ${ }^{67}$ This could be useful in situations where employers allege "neutral" reasons for treating caregivers differently from other workers. Thus, in

disabled workers, and that pregnant women received lower performance ratings than nonpregnant women engaging in identical behavior).

${ }^{61}$ See Krieger, supra note 21 , at 1196-97 (describing how individuals are likely to overestimate the co-occurrence of salient events and characteristics, such as the frequency of negative behaviors by minority group members).

${ }^{62}$ Id. at 1242 .

${ }^{63}$ Liability would be subject to an affirmative defense that the employer would have made the same decision absent the effects of bias comparable to a mixed motive analysis. Id. at 1243. Krieger's approach would reserve compensatory and punitive damages for cases involving conscious use of group status. Id.

${ }^{64}$ See, e.g., Trezza v. The Hartford Inc., No. 98 Civ. 2205, 1998 WL 912101, at *2 (S.D.N.Y. Dec. 30, 1998) (employee was told among other things that "working mothers cannot be both good mothers and good workers" and "women are not good planners, especially women with kids").

65 See, e.g., Sigmon v. Parker Chapin Flattau \& Klimpt, 901 F. Supp. 667, 674 (S.D.N.Y. 1995) (employee who had positive pre-pregnancy reviews received review that she had "come down substantially" following return from maternity leave).

${ }^{66}$ See Desert Palace, Inc. v. Costa, 539 U.S. 90, 101-02 (2003) (holding a mixedmotive instruction may be given to juries without heightened requirement of direct evidence of discrimination).

${ }^{67} \mathrm{Id}$. 
the illustration of the terminated attorney, the employer might be found to have been discriminatory in selecting the plaintiff for layoff if the decision was motivated in part by a stereotypical belief that the plaintiff would probably prefer to stay home. It might also be possible to call into question the supposedly legitimate bases for the attorney's selection for layoff. The supervisor might have taken undue note of the plaintiff's attendance record or limited her assignments based on a misperception about her commitment level. In the pregnant truck driver situation, the plaintiff could argue that despite an otherwise valid distinction between her disability (which was not work-related) and those of previously accommodated workers (who were injured on the job), the employer's decision was to some extent influenced by the seeming incongruity of a pregnant woman driving a truck.

While somewhat less explored, cognitive bias theory might also help male caregivers like the computer programmer in Illustration 3. Some have suggested that men who deviate from the stereotypical male work pattern by assuming significant caregiving responsibilities encounter explicit harassment. ${ }^{68}$ If so, implicit bias based on sex stereotyping may play a role as well. For instance, suppose the programmer takes FMLA leave and is subsequently laid off based on the "legitimate" reason that he does not fit in with his all male work team. That perception may reflect latent assumptions about male caregiving and be subject to challenge as a form of gender discrimination. ${ }^{69}$ It is also possible to envision a failure to accommodate claim by a male worker, due to implicit assumptions about the appropriate division of labor within the family. Thus, some supervisors might make accommodations for women-for instance by making informal arrangements to temporarily reduce workload following maternity leave-but fail to do so for men, based in part on the assumption that fathers should make work their first priority and let their wives handle the family. ${ }^{70}$

As these examples illustrate, cognitive bias theory is only availing in scenarios that replicate a traditional pattern of disparate treatment: either the plaintiff's performance must be equivalent to non-caregivers, or there must be evidence of comparators with similar limitations who were treated better. For this reason, the theory does little more than offer an additional evidentiary route to proving the type of gender stereotyping that the law already recognizes as discriminatory. ${ }^{71}$ Cognitive bias theory has nothing to say about the trucking

${ }^{68}$ See Malin, supra note 4, at 39-42.

${ }^{69}$ See Tristin K. Green, Work Culture and Discrimination, 93 CAL. L. REV. 623, 64650 (2005) (explaining that work culture tends to reflect traditional race and gender norms).

${ }^{70}$ See Hibbs v. Nevada, 538 U.S. 721, 731 (2003) (summarizing the long history of protectionist employer policies geared toward mothers and the exclusion of men from parental leave and other policies accommodating caregiving).

${ }^{71}$ See Price Waterhouse v. Hopkins, 490 U.S. 228 (1989). Presumably, the advantage of cognitive bias theory is that it affords plaintiffs a scientific basis through which to attribute adverse employer behavior to stereotyping despite the absence of explicit comments or conduct. It remains to be seen, however, whether courts will be receptive to hearing social science evidence on this point, as well as whether the plaintiff's bar will be 
company's failure to allow light duty if it does not make such accommodations for similarly situated male employees. Neither would it have any impact if the female attorney or the male computer programmer had been accommodated and their jobs subsequently selected for layoff because they were not working as many hours as others in their positions. ${ }^{72}$

\section{The Mandated Benefit Approach: Caregiver Inclusion as a Fair Labor Standards Obligation}

In contrast, the mandated-benefits approach responds to precisely those scenarios in which caregivers are unable to compete on equal terms as unencumbered workers by requiring employers to accommodate affected employees. Mandated-benefit proposals rely on either the minimum labor standards approach of the FMLA or the accommodation model of the ADA and Title VII vis-à-vis religious discrimination. Proposals building on the FMLA generally seek to supplement the statute's unpaid leave requirement, either by requiring at least partial pay during the leave period ${ }^{73}$ or augmenting the circumstances in which leave may be taken. ${ }^{74}$ Proposals building on the ADA and Title VII seek more tailored accommodations, proposing, for instance, a general duty to "reasonably accommodate" caregiving comparable to the requirement to accommodate disabilities and religious beliefs. ${ }^{75}$

willing to incur the expenses necessary to engage cognitive bias experts.

72 See Ilhardt v. Sara Lee Corp., 118 F.3d 1151, 1152 (7th Cir. 1997) (no discrimination in elimination of part-time position held by female attorney who had moved to part-time status following childbirth).

${ }^{73}$ See, e.g., Selmi, supra note 4, at 770-71 (recommending that federal law be amended to require employers to pay six weeks of FMLA-qualifying leave per worker); Jeremy I. Bohrer, Recent Development, You, Me, and the Consequences of Family: How Federal Employment Law Prevents the Shattering of the "Glass Ceiling," 50 WASH. U. J. URB. \& CONTEMP. L. 401, 420 (1996) (suggesting that employers pay at least a portion of FMLA leave in order to accommodate those employees who could not otherwise afford to take time off).

${ }^{74}$ See Family and Medical Leave Improvements Act of 1997, H.R. 109, 105th Cong. $\S 3$ (1997) (proposing employees be entitled to take an additional twenty-four hours of FMLA leave in any twelve-month period to "participate in school activities directly related to the educational advancement of a son or daughter of the employee, such as parentteacher conferences or interviewing for a new school" and "accompany the son or daughter of the employee to routine medical or dental appointments, such as checkups or vaccinations").

${ }^{75}$ See, e.g., Kessler, supra note 1, at 457-59 (suggesting that the ADA and the religious accommodation provisions of Title VII "offer[] . . . promising model[s] of substantive equality on which to build a theory of workplace accommodation for family caregiving responsibilities"); Smith, supra note 7, at 1445-48, 1465-79 (proposing a model of employer accommodation of family caregiving that would follow the procedural framework associated with religious accommodation claims under Title VII and rely to an 
In all of the previous illustrations, an ADA-like accommodation mandate might enable the plaintiffs to obtain needed alterations in the structure of their jobs. The truck driver would have a legal basis for seeking a lifting restriction or a change in job duties, while the attorney and programmer would each have the right to seek part-time work or some other reduced-time arrangement in addition to any FMLA entitlement. Depending on the circumstances of the individual case, and the definition of reasonableness adopted by courts or the legislature, the employer might be obligated to grant these requests. Under FMLA reform, the effects on these hypothetical plaintiffs would vary depending on the nature of the amendment. Expanding the scope of the FMLA to allow leave for general parenting responsibilities could permit the attorney to work reduced hours in some weeks, albeit without pay. Requiring partial pay would allow the truck driver to draw some compensation while absent due to her pregnancy.

While such approaches could make a meaningful difference to working caregivers if adopted, there are significant pragmatic and normative obstacles to their success. FMLA-type reforms require the selection of specified benefits that may or may not assist all caregivers. As the truck driver example illustrates, more leave (and paid leave, for that matter) is not always the best answer, as where a closely tailored accommodation like disaggregating job duties would enable the employee to continue working. In contrast, generalized accommodation mandates that require a reasonable accommodation suited to the circumstances would allow for such flexibility. Yet, such proscriptions are highly subjective. Existing accommodation mandates have been interpreted narrowly with courts routinely finding unreasonable requests by disabled employees to work from home, restructure their job, or work reduced or flexible hours-the very accommodations that would most help caregivers. ${ }^{76}$ Moreover, the open-ended nature of a "reasonable" accommodation proscription creates significant uncertainty and administrative difficulties for employers. ${ }^{77}$

In addition, the affirmative regulation of employers inherent in the mandatedbenefits approach raises questions about the normative basis for placing additional responsibilities on employers. Accommodation is often equated with "affirmative action" and consequently can occasion backlash from both judges and members of society who mistrust the redistributive agenda of such initiatives. ${ }^{78}$ Some have

extent on unemployment compensation case law to determine when an employee has a compelling family obligation that conflicts with work).

${ }^{76}$ See Arnow-Richman, supra note 10, at 365-66 (summarizing case examples); Travis, supra note 5, at 6 .

${ }^{77} \mathrm{Cf}$. Samuel Issacharoff \& Justin Nelson, Discrimination with a Difference: Can Employment Discrimination Law Accommodate the Americans with Disabilities Act?, 79 N.C. L. REV. 307, 347-55 (critiquing the ADA's imposition of an unspecified redistributive requirement that arbitrarily burdens individual employers).

${ }^{78}$ See Krieger, supra note 13, at 497 (describing the problem of "socio-legal backlash" that occurs "when the application of a transformative legal regime generates outcomes that conflict with norms and institutions to which influenced segments of the relevant populace retain strong conscious allegiance"). 
suggested, for instance, that the constrained judicial approach to interpreting the ADA reflects a lack of commitment to the transformative mission of the statute. ${ }^{79}$ Courts have demonstrated similar ambivalence in interpreting key aspects of the FMLA ${ }^{80}$ and its provisions have been subject to intense criticism by the business community. ${ }^{81}$

More problematic is that developments in the workplace and the economy indicate a shift away from the concept of the employer as a protector and provider for its workforce. Two related developments fuel this trend-the decline in longterm employment and the reduction in employer-provided benefits. ${ }^{82}$ Where careers consist of a series of short-term business transactions rather than a lifetime relationship with a single party, it becomes difficult to justify assigning one employer responsibility for absorbing the inevitable costs of accommodating the life needs of a particular worker. ${ }^{83}$ Moreover, where employees increasingly lack basic benefits like health insurance, it makes little sense to talk of mandating the provision of additional lifecycle benefits.

\section{Conclusion}

Existing approaches to workplace reform have made important contributions to the work/family dialogue, both by theorizing bases for liability absent animus and calling attention to the need for greater accommodation of caregiving. In

79 See id. at 497-98. For additional information on popular sentiment about the ADA's accommodation mandate, see Samuel R. Bagenstos, "Rational Discrimination," Accommodation, and the Politics of (Disability) Civil Rights, 89 VA. L. REV. 825, 910 (2003).

${ }^{80}$ See Arnow-Richman, supra note 10, at 369-73 (describing how courts confuse the FMLA retaliation and interference provisions and mistakenly place the burden of proof on plaintiffs refused reinstatement to prove adverse motive); Martin H. Malin, Interference with the Right to Leave Under the Family and Medical Leave, 7 EMPLOYEE RTS. \& EMP. POL'Y J 329, 358-63 (2003) (describing how courts have falsely dichotomized FMLA retaliation and interference through a misunderstanding of statutory language, resulting in a mistaken analogy between denial of reinstatement and Title VII discrimination claims).

${ }^{81}$ See Sara Schaefer Muñoz, A Good Idea, but . . . : Some Businesses Complain that the Family and Medical Leave Act Should Be More Aptly Named the Slackers Protection Act, WALL ST. J., Jan. 24, 2005, at R6.

${ }^{82}$ For a detailed description of these labor market trends, see generally PETER CAPPElli, THE NeW DEAl AT WorK: MANAGING THE MARKET-DrIVEN WORKFORCE 5964 (1999); Rachel Arnow-Richman, Bargaining for Loyalty in the Information Age: A Reconsideration of the Role of Substantive Fairness in Enforcing Employee Noncompetes, 80 OR. L. REV. 1163, 1198-1202 (2000); Katherine V.W. Stone, The New Psychological Contract: Implications of the Changing Workplace for Labor and Employment Law, 48 UCLA L. REV. 519, 533 (2001).

${ }^{83}$ See Arnow-Richman, supra note 10, at 383 ("[W]ith the demise of the reciprocal social contract of employment, employers are less inclined to view employment relationships as permanent and have only limited incentive to invest in the long-term productivity of individual workers."). 
addition, such initiatives, if successfully pursued, could prove helpful to some caregivers, such as those who require FMLA leave but cannot afford to take it, or those who are able to continue working but are unfairly judged as a result of latent biases. Yet such initiatives are also limited. They build largely on traditional legislative responses to status discrimination - the anti-discrimination model of Title VII and the accommodation model of the ADA, both of which are top-down approaches grounded in substantive legal rights. For this reason, they are likely to fall victim to the problems that plague existing legislation-narrow judicial interpretation of discrimination laws, societal skepticism about the costs and "preferences" associated with accommodation, and, in the case of enhanced benefits initiatives, the inability of specific rules to address the divergent needs and circumstances of all caregivers. It is therefore critical that scholars and advocates devise a viable alternative course of action to supplement the expansion of existing discrimination and family leave law.

\section{The ORganizational Justice Alternative: PRIVATE PRACTICES UNDER PUBLIC SCRUTINY}

Fortunately, a growing trend within discrimination law offers a starting point for an alternative initiative. Increasingly, courts are looking at an employer's responsiveness to the needs of historically excluded workers in interpreting the commands of existing discrimination laws. Thus, under the landmark Supreme Court decisions in Burlington Industries v. Ellerth ${ }^{84}$ and Faragher v. Boca Raton, ${ }^{85}$ employers can assert a defense to sexual harassment hostile work environment liability based on preventative and corrective conduct. ${ }^{86}$ Elsewhere, under the ADA, some circuit courts have examined the process by which employers respond to accommodation requests by disabled workers in assessing liability in substantive failure to accommodate claims. ${ }^{87}$ The former development has touched off a wave of scholarly literature emphasizing the importance of what happens inside firms in ultimately achieving the transformative potential of antidiscrimination law and elaborating on how to harness and encourage proactive behavior by employers. ${ }^{88}$

The result is what I call the "incentivized organizational justice" approach to second-generation exclusion. By use of the term "organizational justice," I refer to approaches that leverage legal rules to encourage proactive personnel practices, in particular employer-administered policies for soliciting and responding to the requests of non-traditional employees. As this definition suggests, the belief that underlies such an approach is that employers must play an affirmative role in

${ }^{84} 524$ U.S. 742 (1998).

85 524 U.S. 775 (1998).

${ }^{86}$ See id. at 807 ; Ellerth, 524 U.S. at 764 ; infra Part III.A.1.

${ }^{87}$ See, e.g., Barnett v. U.S. Air, Inc., 228 F.3d 1105, 1116 (9th Cir. 2000); see infra Part III.A.2.

${ }^{88}$ See, e.g., Estlund, supra note 14, at 378-83; Sturm, supra note 1, at 491-520; see infra Part IV.A. 
eliminating disparities in employment quality in order for any legislative effort to be successful. In the section that follows, I provide two practical illustrations of how such approaches have worked and how they can be strengthened, before turning to how these ideas can be adapted in the context of caregiver exclusion. In so doing, I will expose what I consider to be the three key characteristics of incentivized organizational justice: a focus on the organic internal practices of companies as opposed to externally constructed standards of conduct, the use of monetary penalties and liability presumptions to provide incentive for inclusive behavior by employers, and a move away from intent to harm toward an assessment of preventative and responsive action in determining fault and consequently liability.

\section{A. Judicial Adoption of Organizational Justice Principles: Risks and Potential}

\section{Vicarious Liability for Supervisory Sexual Harassment}

The most visible move to consider employers' internal procedures in antidiscrimination law is the development of the Ellerth/Faragher affirmative defense to hostile work environment liability. Under this defense, employers will be relieved of liability for harassing behavior that does not culminate in a tangible employment action if they can show, among other things, that they engaged in preventative and corrective measures to avoid harassment. ${ }^{89}$

The Supreme Court established the affirmative defense in a pair of cases addressing the availability of vicarious liability for hostile work environment harassment. ${ }^{90}$ Unlike traditional quid pro quo harassment, in which the employer exercises its discretion to affect the employee's status at work, hostile work environment harassment can occur absent employer support or even awareness. In light of this, the Court concluded the employer should be held responsible in those cases where it aided the harasser by failing to prevent or correct such behavior. ${ }^{91}$ Specifically, the Court held that an employer would not be liable where it could prove: (1) the employer exercised reasonable care to prevent and correct promptly any sexually harassing behavior; and (2) the employee unreasonably failed to take advantage of any preventative or corrective opportunities provided by the employer, or otherwise avoid harm. ${ }^{92}$

Although the Court's analysis was grounded in basic agency principles, ${ }^{93}$ many aspects of its decision are consistent with an organizational justice approach to equal employment quality. An ideal interpretation and application of the affirmative defense looks to the employer's voluntary policies and practices in

\footnotetext{
${ }^{89}$ See Faragher, 524 U.S. at 807 ; Ellerth, 524 U.S. at 764.

${ }^{90}$ See Faragher, 524 U.S. at 807; Ellerth, 524 U.S. at 764.

${ }^{91}$ See Faragher, 524 U.S. at 808-09; Ellerth, 524 U.S. at 758-59.

92 See Faragher, 524 U.S. at 807; Ellerth, 524 U.S. at 765.

${ }^{93}$ See Faragher, 524 U.S. at 783-94; Ellerth, 524 U.S. at 754-60.
} 
assessing liability, thus tying fault to the absence of positive, proactive behavior rather than the presence of affirmative misconduct. ${ }^{94}$ The question is whether the employer has enabled discriminatory behavior and/or discriminatory results through its inaction. In this way, in theory, it provides incentive for more conscientious behavior by employers.

In operation, however, the defense has become a lightening rod for criticism. The general consensus, as well as the conclusion of some empirical data, is that plaintiffs lose under the new standard. ${ }^{95}$ One reason for this is courts' apparent willingness to conclude that a company that maintains and disseminates a sexual harassment policy satisfies the first prong of the defense. ${ }^{96}$ This conclusion is problematic in two respects. First, it assumes without question that a paper policy and related human resources measures, such as training, are effective responses to sexual harassment. ${ }^{97}$ Second, it may preclude court consideration of what are arguably more relevant and situationally specific matters such as the extent the employer actively polices hostility in the workplace and the employer's responsiveness to the particular complaint. ${ }^{98}$ The feared result is a culture of "paper

${ }^{94}$ See Faragher, 524 U.S. at 808-09 (holding as a matter of law that the defendant city could not have been found to have acted with reasonable care because it "had entirely failed to disseminate its policy against sexual harassment among the beach employees and ... its officials made no attempt to keep track of the conduct of [its] supervisors").

${ }^{95}$ See Stephen F. Befort \& Sarah J. Gorajsk, When Quitting is Fitting: The Need for a Reformulated Sexual Harassment/Constructive Discharge Standard in the Wake of Pennsylvania State Police v. Suders, 67 OHIо ST. L.J. 593, 641-42 (2006); Susan BisomRapp, An Ounce of Prevention Is a Poor Substitute for a Pound of Cure: Confronting the Developing Jurisprudence of Education and Prevention in Employment Discrimination Law, 22 BERKELEY J. EMP. \& LAB. L. 1 (2001); Ann Lawton, Operating in an Empirical Vacuum: The Ellerth and Faragher Affirmative Defense, 13 COLUM. J. GENDER \& L. 197 (2004); John H. Marks, Smoke, Mirrors, and the Disappearance of "Vicarious" Liability: The Emergence of a Dubious Summary-Judgment Safe Harbor for Employers Whose Supervisory Personnel Commit Hostile Environment Workplace Harassment, 38 Hous. L. REV. 1401 (2002).

${ }^{96}$ See Samuel R. Bagenstos, The Structural Turn and the Limits of Antidiscrimination Law, 94 CAL. L. REV. 1, 25 (2006) (describing judicial unwillingness to engage in rigorous scrutiny of employer procedures despite Supreme Court precedent); David Sherwyn et al., Don't Train Your Employees and Cancel Your "1-800" Harassment Hotline: An Empirical Examination and Correction of the Flaws in the Affirmative Defense to Sexual Harassment Charges, 69 FORDHAM L. REV. 1265, 1283-85 (2001) (finding the existence of a sexual harassment policy to be the only factor to statistically predict an award of summary judgment in an employer's favor).

${ }^{97}$ See Lawton, supra note 95, at 198, 207, 212, 222 (arguing that empirical evidence of the effectiveness of employer policies is lacking); Margaret S. Stockdale et al., Coming to Terms with Zero Tolerance Sexual Harassment Policies, 4 J. FORENSIC PSYCHOL. PRAC. $65,73-74$ (2004) (explaining that organizational climates are not formed on the basis of written rules).

${ }^{98}$ See Stockdale et al., supra note 97 , at 72 (finding in a study of courts' treatment of zero tolerance polices that courts paid little attention to effectiveness and overall workplace culture in assessing liability). 
compliance" $" 99$ that may ultimately lower the bar on what employers need to do to avoid liability. ${ }^{100}$

Certainly this aspect of the affirmative defense experiment should give us pause before adopting other organizational justice approaches to discrimination liability. However, it should not bring the trend to a full stop. A few courts have understood the defense and gotten the results right. These courts have denied summary judgment to employers invoking the defense, leaving it to the jury to assess the quality of the employer's policies and its response to the particular incident. ${ }^{101}$ While this interpretation is not as prevalent as one would hope, it at least demonstrates the potential for a rigorous factual inquiry into employer conduct.

The gap between potential and reality in many Ellerth/Faragher cases can be explained by at least two facts: the defense is entirely judicial in source, and it reflects a latent policy choice on which there appears to be vast disagreement. With respect to the first point, the Supreme Court's articulation of the defense lacks precision and is couched in dicta that invite the paper-focused interpretation of the lower courts. The Court frames its holding as a two-prong defense, with the first prong focusing on the employer's policies and conduct, and the second focusing on the conduct of the victim. ${ }^{102}$ In reality, the first prong contains two necessary subelements - the employer must exercise reasonable care to prevent and correct harassment. ${ }^{103}$ The existence of a sexual harassment policy may demonstrate efforts to prevent harassment, but it does not speak to the quality of the employer's corrective action. Yet in Ellerth and Faragher, the Court goes on to discuss harassment policies as an example of facts relevant to the inquiry to be conducted under the first prong. ${ }^{104}$ Many lower courts appear to have taken that dictum to

${ }^{99}$ Samuel R. Bagenstos, The Structural Turn, supra note 96 at 24; see also Stockdale et al., supra note 97, at 72 (warning of the likelihood of symbolic compliance by employers).

${ }^{100}$ Concern over a dilution in liability standards is informed by the theory of legal endogeneity, which suggests that regulated actors not only respond to legal directives, but in so doing shape the development of the law. See Lauren B. Edelman, The Endogeneity of Legal Regulation: Grievance Procedures as Rational Myths, 105 AMER. J. OF SOC. 406, 407 (1999). As applied in this context, the theory would suggest that the policies and procedures adopted by employers in response to the preventative action component of the Supreme Court's affirmative defense will form a baseline that courts will use in evaluating compliance efforts.

${ }_{101}$ See, e.g., Wells v. Happy Tymes Family Fun Ctr., Inc., No. 04-5354, 2005 WL 3111783 , at *2 (E.D. Pa. Nov. 21, 2005); Dowling v. Home Depot, No. 02-3181, 2003 WL 40741, at *3 (E.D Pa. Jan. 2, 2003).

${ }_{102}$ See Faragher v. City of Boca Raton, 524 U.S. 775, 807 (1998) ("The [affirmative] defense [to liability] comprises two necessary elements."); Burlington Indus., Inc. v. Ellerth, 524 U.S. 742, 765 (1998) (same).

${ }^{103}$ Ellerth, 524 U.S. at 765 ("[The first prong is] that the employer exercised reasonable care to prevent and correct promptly any sexually harassing behavior.").

${ }^{104}$ See Faragher, 524 U.S. at 807-08; Ellerth, 524 U.S. at 765 ("While proof that an employer had promulgated an anti-harassment policy with complaint procedure is not 
heart, placing undue emphasis on that single aspect of the prevention sub-element of first prong of the test. Thus, the Court's choice of example, combined with its failure to segregate what implicitly are two separate requirements, has contributed to a misinterpretation by lower courts that emphasizes prevention at the expense of a more fact-intensive inquiry into corrective action.

Second, any incentive to paper compliance is exacerbated by the Supreme Court's suggestion that where both employer and employee are equally blameless, vicarious liability attaches. A common harassment scenario involves an employer that makes reasonable efforts to prevent harassment, the occurrence of a harassing event notwithstanding those efforts, a timely complaint by the victim, followed by reasonable corrective action by the employer. In this situation, the employer has done no wrong, but remains vicariously liable; whenever a victim timely reports, the employer is unable to establish the second prong of the affirmative defense, that the plaintiff "unreasonably failed to take advantage of any preventative or corrective opportunities" of the employer. ${ }^{105}$ Presumably the Supreme Court intended that result insofar as it made the two prongs of its test conjunctive. ${ }^{106}$ However the particular factual scenario was not before it: in both Ellerth and Faragher the victim delayed reporting until after she left employment and the employer's preventative efforts were less than ideal. ${ }^{107}$ This has allowed some lower courts, sheepish about assigning liability to blameless employers, to distinguish Ellerth and Faragher and award summary judgment notwithstanding the instructions of the Court. ${ }^{108}$

Of course, the underlying question as to who should bear the loss between two innocents is an important and controversial question, but not one that will be resolved in this Article. ${ }^{109}$ The point, rather, is to understand why judicial

necessary in every instance as a matter of law, the need for a stated policy suitable to the employment circumstances may appropriately be addressed in any case when litigating the first element of the defense.").

${ }^{105}$ Faragher, 524 U.S. at 807 ; Ellerth, 524 U.S. at 765.

106 See Faragher, 524 U.S. at 797 (citing a tort treatise stating "'the integrating principle' of respondeat superior is 'that the employer should be liable for those faults that may be fairly regarded as risks of his business, whether they are committed in furthering it or not"' (citations omitted)); Ellerth, 524 U.S. at 758 (noting that, in limited circumstances, "agency principles impose liability on employers even where employees commit torts outside the scope of employment").

${ }^{107}$ See Faragher, 524 U.S. at 782 (noting that the defendant "completely failed to disseminate its policy among employees of the Marine Safety Section, with the result that [members of the Plaintiff's work group] were unaware of it"); Ellerth, 524 U.S. at 748 (noting that the plaintiff first complained of behavior in a letter of explanation three weeks after quitting).

${ }^{108}$ See Marks, supra note 95, at 1423 (critiquing courts' response to "rapid onset harassment").

${ }^{109}$ On this issue, see generally Seth D. Harris, Innocence and the Sopranos, 49 NEW YORK L. SCH. L. REV. 577 (2004-05) (questioning the definition of innocence as understood by courts and its ultimate relevance to the project of redressing workplace discrimination). 
application of the affirmative defense has been a disappointment to some commentators in order to clarify its significance to future organizational justice approaches to liability. What should be clear is that a rule that attaches liability to a faultless employer is not applying organizational justice principles at all; it is asserting a normative judgment that it is better to charge a blameless employer than allow an innocent victim to go uncompensated. Indeed, in some respects the Ellerth/Faragher defense actually discourages the type of proactive behavior that the organizational justice model seeks to reward and encourages symbolic compliance. Since an employer will be liable whenever an employee properly reports, it is arguably in its interest to engage in preventative measures that technically satisfy the first prong of the defense, but which fall short of creating a work climate that truly encourages employees to come forward. ${ }^{110}$

Thus, the Ellerth/Faragher defense, while problematic in some applications, certainly should not be taken as a general referendum on the viability of further organizational justice approaches to discrimination liability. Future legislative or Supreme Court action can save the harassment defense by clarifying the relationship between the two sub-elements of the first prong of the defense and reemphasizing the need for the type of fact-intensive inquiry that generally requires jury deliberation. More importantly, the organizational justice component of the defense is limited to its first prong, which requires employers to engage in preventative and corrective action. To the extent that principle is intertwined with what is effectively a strict liability mandate in the second prong of the defense, it does not provide a reliable example of the value and potential of a pure organizational justice approach to liability.

\section{2. "Interactive Process" Obligations Under the ADA}

A less noted, but arguably more successful, example of an organizational justice approach to employment discrimination liability is judicial consideration of employer/employee cooperation in assessing liability for failure to accommodate disabled workers under the ADA. Several circuits have held that the ADA requires employers who have reason to know of an employee's disability to engage in an "interactive process" with that individual," and emphasis on the development of such a process is a core part of the legal and human resources compliance literature. $^{112}$

${ }^{110}$ See Sherwyn et al., supra note 96 , at $1280-84$ (arguing that the affirmative defense creates perverse incentives to discourage reporting, and recommending elimination of the second prong of the defense).

${ }^{111}$ See, e.g., Barnett v. U.S. Air, Inc., 228 F.3d 1105, 1116 (9th Cir. 2000); Bartee v. Michelin N. Am., Inc., 374 F.3d 906, 916 (10th Cir. 2004); Beck v. Univ. of Wis. Bd. of Regents, 75 F.3d 1130, 1135 (7th Cir. 1996); Jamison v. Dow Chem. Co., 354 F. Supp. 2d 715, 733 (E.D. Mich. 2004); Picinich v. United Parcel Serv., 321 F. Supp. 2d 485, 511 (N.D.N.Y. 2004).

${ }^{112}$ See, e.g., Stephen F. Befort, Accommodation at Work: Lessons from the Americans with Disabilities Act and Possibilities for Alleviating the American Worker Time Crunch, 
The idea of constructive interaction between employers and employees as a means of achieving accommodation stems from Equal Employment Opportunity Commission ("EEOC") interpretative regulations to the ADA. These provide that in order to determine whether an employee is entitled to an accommodation "it may be necessary for the [employer] to initiate an informal, interactive process" with that individual. ${ }^{113}$ The purpose of the process is to "identify the precise limitations resulting from the disability and potential reasonable accommodations that could overcome [them]." 114 Despite the permissive language of the regulation, most courts have held that employers have an affirmative duty to engage in the interactive process. The obligation is triggered either by the employee's request for accommodation, or, in situations where the employee's disability or need for accommodation is apparent, the employer's actual or constructive knowledge of the situation. ${ }^{115}$

13 CORNell J.L. \& PUB. POL'Y 615, 622-28 (2004) (describing the "procedural revolution" under the ADA); Hope A. Comisky, Guidelines for Successfully Engaging in the Interactive Process to Find a Reasonable Accommodation Under the Americans with Disabilities Act, 13 LAB. LAW. 499, 502-09 (1998) (discussing the steps an employer should take to ensure compliance with the interactive process); PollyBeth Proctor, Determining 'Reasonable Accommodation' Under the ADA: Understanding Employer and Employee Rights and Obligations During the Interactive Process, 33 Sw. U. L. REV. 51, 55-72 (2003) (surveying the circuit courts' varying treatments of the interactive process requirement for reasonable accommodations in the employment context under Title I of the ADA); Stanley J. Smits, Disability and Employment in the USA: The Quest for Best Practices, 19 DISABILITY \& SOC'Y 647, 658 (2004) (determining that employers engage in the best employment practices in the disability arena when "(a) service providers and persons with disabilities have employment as a convergent priority; (b) investments in public awareness create a climate for collaboration and systems integration; and (c) when employers are brought on-board and get involved at a personal level").

${ }_{113}^{13} 29$ C.F.R. \& 1630.2(o)(3) (2006).

${ }_{114} I d$.

115 See Conneen v. MBNA Am. Bank, N.A., 334 F.3d 318, 332 (3d Cir. 2003) (" $[C]$ ircumstances will sometimes require " $[t]$ he employer ... to meet the employee halfway, and if it appears that the employee may need an accommodation but doesn't know how to ask for it, the employer should do what it can to help."' (quoting Bultemeyer v. Fort Wayne Cmty. Sch., 100 F.3d 1281, 1285 (7th Cir. 1996) (alteration in original))); Barnett, 228 F.3d at 1114 ("[I]f the company knows of the existence of the employee's disability, the employer must assist in initiating the interactive process."); Smith v. Midland Brake, Inc., 180 F.3d 1154, 1172 (10th Cir. 1999) (stating that "expressing a desire for reassignment" to a different position within the company need not include any magic words; rather, "the employee must convey to the employer a desire to remain with the company despite his or her disability"); Nagel v. Sykes Enters., Inc., 383 F. Supp. 2d 1180, 1192 (D.N.D. 2005) ("“A request for accommodation, while it need not contain any magic words, must be sufficient to convey to the employer that the employee is requesting that his disability be accommodated."' (quoting Lowery v. Hazelwood Sch. Dist., 244 F.3d 654, 660 (8th Cir. 2001))); Mihalko v. Potter, No. 00-2076, 2003 WL 23319594, at *12 (W.D. Pa. 2003) (" $[\mathrm{N}]$ otice need not be in writing, be made by the employee himself, or formally invoke the magic words reasonable accommodation, the notice nonetheless must make 
Underlying the obligation is the belief that process is necessary for parties to reach appropriate solutions to the work limitations posed by a disability, recognizing that neither employers nor employees can find optimal accommodations on their own. Employees do not know the range of possible positions or job adaptations that may be available within the organization. ${ }^{116}$ Similarly, employers do not have expertise in the nature of the employee's disability and cannot know what kinds of job alterations would be helpful. ${ }^{117}$ By focusing the parties toward achieving a joint result, the interactive process steps outside the zero-sum game associated with mandated-benefit legislation.

In application, courts must examine the quality of the parties' interaction, assess the good faith of each side, and determine who is responsible for the failure to achieve an accommodation. ${ }^{118}$ For instance, the Ninth Circuit Court of Appeals in Barnett v. U.S. Air, Inc., found U.S. Air liable for a breakdown in the interactive process surrounding a disabled customer service agent's request to remain in a mailroom position as an accommodation. ${ }^{119}$ Upon injuring his back in a cargo position, the plaintiff used seniority rights to transfer to a mailroom position. ${ }^{120}$ Later, when he learned that more senior employees who planned to transfer to the mailroom might bump him back to cargo, he requested permission to remain in the mailroom as a reasonable accommodation. ${ }^{121}$

clear that the employee wants assistance for his or her disability." (quoting Jones v. United Parcel Serv., 214 F.3d 402, 408 (3d Cir. 2000) (internal quotation marks omitted))).

${ }^{116}$ See Barnett, 228 F.3d at 1113 (noting that exploring accommodations for an employee requires participation of the employer because he or she has "superior knowledge regarding the range of possible positions and can more easily perform analyses regarding the 'essential functions' of each" (quoting Taylor v. Phoenixville Sch. Dist., 184 F.3d 296, 316 (3d Cir. 1999))); cf. Smith, 180 F.3d at 1173 ("[I]n a small company an employee might be reasonably expected to know what other jobs are available for which he or she may be qualified to perform. [sic] On the other hand, in larger companies or companies where the employee does not have ready access to information regarding available jobs, it might be reasonable to require the employer to identify jobs that the employer reasonably concludes are appropriate for reassignment consideration.").

${ }^{117}$ See Barnett, 228 F.3d at 1113 ("[T]he employee holds essential information for the assessment of the type of reasonable accommodation which would be most effective .... [E]mployees generally know more about their own capabilities and limitations.").

${ }^{118}$ See EEOC v. Sears, Roebuck \& Co., 417 F.3d 789, 805 (7th Cir. 2005) (explaining that no hard and fast rule exists to determine which party was responsible for the breakdown in the process; rather courts that address this issue should "isolate the cause of the breakdown and then assign responsibility"); Beck v. Univ. of Wis. Bd. of Regents, 75 F.3d 1130, 1135 (7th Cir. 1996) ("[N]either party should be able to cause a breakdown in the process for the purpose of either avoiding or inflicting liability. Rather, courts should look for signs of failure to participate in good faith or failure by one of the parties to make reasonable efforts to help the other party determine what specific accommodations are necessary.").

119228 F.3d at 1122

${ }^{120} \mathrm{Id}$.

${ }^{121}$ Id. at $1108-09$. 
On the question whether the employer violated the ADA interactive process requirement, the Ninth Circuit evaluated the company's response and found it wanting. ${ }^{122}$ U.S. Air did not reply to Barnett for five months, at which point the response consisted of a supervisor informing Barnett that he would be placed on involuntary job injury leave. ${ }^{123}$ The employer did not engage in any substantive discussion of Barnett's condition, the kinds of limitations that it imposed, or what could be done to accommodate him. ${ }^{124}$ Following this meeting, Barnett sent a second letter proposing two alternative accommodations within the cargo position: that the employer purchase a type of lifting device or restructure the position so he would do only warehouse office work. ${ }^{125}$ Both of these requests were also denied, by letter, with instructions that Barnett could bid for jobs "within his restrictions." 126

Ultimately, the Supreme Court determined on appeal that Barnett's proposal to remain in the mailman was not reasonable because it would have violated other workers' seniority rights. ${ }^{127}$ However, the Court did not certify for review the independent part of the Ninth Circuit decision addressing the process by which the employer decided to refuse the accommodation. ${ }^{128}$ Thus, it left standing the ruling that U.S. Air had failed to fulfill a mandatory obligation under the ADA and that statutory liability "would be appropriate if a reasonable accommodation would otherwise have been possible." 29

A better approach to handling employee requests for accommodation can be seen in Beck v. University of Wisconsin Board of Regents. ${ }^{130}$ In that case a secretary suffering from osteoporosis and depression made several requests for accommodation, many of which were granted. ${ }^{131}$ Importantly, on Beck's return

${ }^{122}$ Id. at 1108 .

${ }^{123} \mathrm{Id}$. at 1117 .

${ }^{124} \mathrm{Id}$. at 1109.

${ }^{125} \mathrm{Id}$.

${ }^{126} \mathrm{Id}$

${ }^{127}$ See US Airways, Inc. v. Barnett, 535 U.S. 391, 403-05 (2002) (discussing the importance of preserving seniority rights to ensure strong employee-management relations where the system fulfills expectations of uniform and fair treatment), vacating U.S. Air, Inc., v. Barnett, 228 F.3d 1105 (9th Cir. 2000).

${ }^{128}$ US Airways, Inc. v. Barnett, 532 U.S. 970 (No. 00-1250) (April 16, 2001) (granting certiorari to the Ninth Circuit "limited to Question 1 presented by the petition"); Petition for a Writ of Certiorari at i, 2001 WL 34091942 (posing the following questions: " 1 . Whether... the ADA requires an employer to reassign a disabled employee to a different position as a 'reasonable accommodation' even though another employee is entitled to hold the position under the employer's bona fide and established seniority system....2. Whether... evidence of an employer's failure to engage in an interactive process with a disabled employee to identify reasonable accommodations precludes the employer from obtaining summary judgment in an ADA action").

${ }^{129}$ Barnett, 228 F.3d at 1117.

13075 F.3d 1130, 1132 (7th Cir. 1996).

${ }^{131}$ The employer attempted to accommodate Beck by providing a wrist rest, a reduced workload, office relocation, and medical leave. Id. 
from medical leave, the University made an effort to determine what Beck needed in order to perform her job-it scheduled a meeting with her, requested that she provide medical information from her physician, and asked her by memo to provide more details about her disability and how she needed to be accommodated. ${ }^{132}$ Similarly, in Jamison $v$. Dow Chemical Co., an engineer technician in a chemical plant developed an eye condition that prevented him from working near dust, fumes, and vapors. ${ }^{133}$ After some initial efforts to accommodate him within his building (for instance, by providing protective eye gear), Jamison was referred to an in-house training resource responsible for repurposing company employees for a variety of reasons including medical restrictions. ${ }^{134}$ The head of the training resource program implemented his procedure for handling such referrals, which consisted of gathering information about the worker's medical restrictions, informing production leaders about the availability of particular medically restricted personnel, and following up with those individuals to find out about possible staffing needs. ${ }^{135} \mathrm{He}$ placed Jamison in at least five positions before reaching the conclusion that work in a chemical plant in any capacity was incompatible with the employee's condition. ${ }^{136}$

Obviously it is better for employees if employers take the approach to accommodation adopted by the University of Wisconsin and Dow Chemicals than U.S. Air's approach. The question is: what role does the law play in encouraging that behavior? Certainly the reasonable accommodation requirement creates an incentive to engage in some type of process even absent a legal requirement to do so, and indeed employers have been doing so for some time. Yet it is also possible to imagine tying penalties or other substantive legal consequences to procedural violations so that procedural obligations provide meaningful incentives in their own right.

For instance, while most courts have held that liability ensues for failure to engage in an interactive process only if a reasonable accommodation would have been available, ${ }^{137}$ several have taken account of the procedural requirement in ruling on summary judgment. These courts have held that evidence of the employer's failure to engage in an interactive process precludes an award of

132 Beck never responded to this request, nor did she provide the necessary information and, after an extended period of trial and error with different work arrangements, she was terminated. $I d$. at 1133 .

${ }_{133}$ Jamison v. Dow Chem. Co., 354 F. Supp. 2d 715, 719 (E.D. Mich. 2004).

${ }^{134} \mathrm{Id}$. at 722 .

${ }^{135} \mathrm{Id}$.

${ }^{136} I d$. at 725 .

${ }^{137}$ See, e.g., Barnett v. U.S. Air, Inc., 228 F.3d 1105, 1116 (9th Cir. 2000); Taylor v. Phoenixville Sch. Dist., 184 F.3d 296, 317-18 (3d Cir. 1999); Smith v. Midland Brake, Inc., 180 F.3d 1154, 1174 (10th Cir. 1999); Bultemeyer v. Fort Wayne Cmty. Sch., 100 F.3d 1281, 1285 (7th Cir. 1996); Taylor v. Principal Fin. Group, Inc., 93 F.3d 155, 165 (5th Cir. 1996). 
summary judgment on the plaintiff's substantive failure to accommodate claim. ${ }^{138}$ This approach has its difficulties. Indeed, it seems problematic to suggest that summary judgment should be denied automatically on the basis of a process failure where the plaintiff does not have the facts necessary to sustain a substantive claim. For instance, given the prevailing interpretation of reasonable accommodation, if an employer flatly denies without any consideration a disabled employee's request to work reduced hours, it would be futile to require a trial in the face of evidence that all employees in the plaintiff's position work full-time and the employer has previously denied reduced time for non-disabled individuals. ${ }^{139}$

That said, the underlying motivation for the approach is the notion that proactive employer behavior is an integral part of achieving equal employment quality for non-traditional workers. By denying summary judgment on the accommodation claim, courts put the quality of worker due process at the center of the substantive inquiry under the statute. The implication is that what might at first seem an untenable conflict between the needs of a worker and the needs of the business may in fact be reconcilable if only the parties can educate each other through an objective process. If courts operate under this assumption, and can succeed in creating effective and administrable litigation incentives, they may realize the full potential of an organizational justice approach, one that not only rewards good behavior, but targets exclusion at its source - the extant managerial and operational procedures that have been developed and shaped by mainstream workers over the years without the input of non-traditional employees. By advantaging those employers that engage with their workforce, courts can value and encourage the development of cultures of inclusion that may help erode organizational barriers to success.

Perhaps most importantly, judicial attention to employer behavior is emerging despite courts' limited interpretation of the scope of the substantive rights created by the ADA. Arguably the most aggressive of the federal equal employment opportunity laws, the ADA's accommodation mandate has often been criticized for failing to achieve significant changes in work structure. ${ }^{140}$ At the same time there is research to suggest that whatever the statistics on the success of such claims or the scope of the accommodation mandate, the ADA has had a significant impact on the perception of disabled workers and their ability to have a voice in the workplace. ${ }^{141}$ The interactive process jurisprudence suggests one way in which the

${ }^{138}$ See, e.g., Fjellestad v. Pizza Hut of Am., Inc., 188 F.3d 944, 953 (8th Cir. 1999); Phoenixville Sch. Dist., 184 F.3d at 318; see generally Befort, supra note 112 , at 627-28 (explaining competing judicial approaches to the consequences of an interactive process violation).

${ }^{139}$ See, e.g., Davis v. Microsoft Corp., 37 P.3d 333, 335 (Wash. Ct. App. 2002).

${ }^{140}$ See, e.g., Arnow-Richman, supra note 10, at 363-67; Travis, supra note 5, at 6.

141 See, e.g., David M. Engel \& Frank W. Mungel, Rights of InClusion: LAW AND IDENTITY IN THE LifE STORIES OF AMERICANS WITH DisABILITIES 243-44 (2003) (concluding that ADA rights become "active" through their influence on personal identity of disabled persons, cultural and discursive shifts, and institutional transformations regardless of whether disabled individuals explicitly invoke legal rights); Befort, supra 
law creates that effect. Although courts may be uncomfortable compelling employers to alter their work practices, they are willing to penalize those who do not make an effort to accommodate. Thus, there is reason to believe that the ADA is giving disabled workers a leg up in negotiating with their employers and, as a consequence, is achieving favorable, cooperatively designed solutions under the radar of reported case law.

\section{B. Organizational Justice for Caregivers: Procedural Rights Plus Incentivized Accommodation}

Having surveyed recent organizational justice moves in other areas of discrimination law, this subsection turns to harnessing the potential of incentivized organizational justice to achieve positive results for caregivers while studiously avoiding some of its pitfalls. It puts forth a two-part proposal consisting of a legislative amendment to the FMLA and a reinterpretation of the burden of proof on FMLA and Title VII claims. Specifically, it calls first for an added provision to the FMLA that would require employers to engage in a good-faith interactive process with workers, both when the need for leave arises and when affected workers return to work, or face a monetary penalty. Second, it argues for a judicially created burden shift on proof of substantive violations of the FMLA and Title VII in cases where employers fail to engage in a good-faith process and the plaintiff can demonstrate a prima facie case of retaliation or discriminatory failure to accommodate. The first component adopts the ADA interactive process concept, but makes the threat of a procedural violation meaningful through the imposition of a statutory fee. The second component draws on the first prong of the Ellerth/Faragher defense, but makes clear that avoiding a burden shift turns on the quality of the employer's response to the particular accommodation request rather than general compliance efforts.

\section{Statutory Damages for Procedural Violations}

A simple and potentially fruitful change to the statutory cannon can be achieved by amending the FMLA to include an interactive process requirement similar to that which exists under the ADA. In addition to providing twelve weeks of unpaid leave, the Act could require employers to engage in a good-faith, interactive process with qualifying employees to consider ways of altering their work schedules (or work requirements) to effect a needed accommodation. At a minimum this procedural obligation would be triggered in two circumstances:

note 112, at 626 (asserting that although "the accommodation model may not have produced a revolution in the substantive law arena....the interactive process contemplated by the ADA ... has launched untold numbers of successful workplace accommodations"). 
when an employee experiences a qualifying caregiving-related event or when an employee returns from FMLA leave taken for such purposes. ${ }^{142}$

Such an approach represents an initial step toward addressing what is perhaps the strongest criticism of the FMLA: that the Act is event-centered, treating birth, adoption and family illness as discrete moments rather than life-long experiences. A procedural requirement imposed on the employer upon the conclusion of FMLA leave recognizes, for instance, that an employee who gives birth or adopts a new child cannot be expected to seamlessly return to full-time work upon the conclusion of the child's third month. ${ }^{143}$ Rather, such a law supposes that any time a qualifying event occurs, additional accommodations beyond leave may well be necessary and can potentially be achieved through mutual agreement where parties meet in a meaningful attempt to assess the employee's situation and any limitations that he or she might face upon returning to work.

Similarly, an interactive process can refine, in some situations, the blunt effect of a one-size-fits-all mandated benefit. By engaging in a good-faith process at the onset of a qualifying event, parties may be able to identify alternative accommodations that are more closely tailored to the employee's situation and just as viable for the employer. For instance, there may be situations in which a relatively simple job modification will enable a pregnant employee to continue working and allow the employer to avoid the disruption of a temporary replacement. It may also be possible to work out a flexible schedule that enables an employee caring for a seriously ill family member to maintain close to full-time

142 Because this Article deals specifically with challenges faced by working caregivers, my proposal focuses on employees eligible for FMLA leave based on birth, adoption, pregnancy, or the serious health condition of a family member. I note, however, that because a process amendment does not create any additional substantive rights, there would appear to be little harm in including within the mandate employees experiencing their own serious health conditions other than pregnancy. Similarly, it may be possible to apply this limited procedural component to a broader group of working caregivers than those who are FMLA-eligible. For instance, one might require the employer to engage in the interactive process with workers who experience caregiving conflicts that do not trigger FMLA leave, such as a non-serious illness of a family member. Also, it might be appropriate to place this obligation on all employers, not only those that meet the FMLA requirement of employing fifty or more workers, given that the provision would impose only the negligible costs and burdens of engaging in the process itself, without requiring those employers to supply the twelve-week leave. A thorough consideration of whether procedural rights would be appropriate or effective in those situations, however, is a topic beyond the scope of this Article.

${ }_{143}$ See Deborah L. Rhode, Response Essay: Balanced Lives, 102 ColuM. L. .REV.. 834,845 (2002) (noting that "twelve weeks falls short of what child development experts believe is minimally necessary" for the amount of time a mother should remain at home with her child after birth ); Joan Williams, Our Economy of Mothers and Others: Women and Economics Revisited, 5 J. GENDER RACE \& JUST.. 411, 430 (2002) (critiquing the FMLA for "account[ing] for only three months of child-rearing, a task that lasts twenty years"). 
employment and avoid the administrative difficulties associated with the use of intermittent leave.

Of course, the right described here would be limited to the right to request and discuss; it would not compel the employer to accommodate the worker, but merely facilitate voluntary solutions. This is critical to the political viability of the proposal both in terms of congressional adoption and the reliability of judicial enforcement. By the same token, the absence of an underlying substantive right to accommodation means that care must be taken to ensure employer accountability under the amendment. The worker's procedural rights must be enforced by a monetary penalty sufficient to deter noncompliance. ${ }^{144}$ One possibility, for instance, would be to require liquidated damages equivalent to twice the employee's pay for the twelve-week FMLA leave period. In addition, violations must include not only blatant failures to meet and discuss, but also the failure to act in good faith, as where an employer implements a process in name only and gives no meaningful consideration to the employee's request. ${ }^{145}$ The effect of any remedial scheme could be enhanced by making the denials publicly available through a government or industry publication that would have reputational consequences for the employer.

\section{Litigation Penalties for Failure to Act in Good Faith}

As a further incentive, an employer's procedural failures could result in a presumption of employer liability on certain substantive claims under the FMLA and Title VII. While similar to the idea underlying the denial of summary judgment for interactive process violators under the ADA, the litigation penalty would take the form of a judicially created shift in the burden of proof ${ }^{46}$ on FMLA retaliation claims and Title VII discriminatory failure to accommodate claims. ${ }^{147}$ In

144 Since the employee has no right to accommodation, the damages should not be based on any loss of work or denial of a particular accommodation.

${ }^{145}$ The invocation of good faith in this context calls to mind the employer's obligation to bargain in good faith with a union representative. While that body of law may be the most obvious analogy for this inquiry, it would not likely be the most fruitful, given the extremely limited scrutiny applied to employer actions in that context. A full development of the nature of the proposed duty to consider employee accommodation requests, as well as the scope of court review of the employer's process, must await a further article. It should be noted, however, that there are numerous legal models from which to draw other than the labor law obligation to bargain in good faith, including some outside the employment arena, such as judicial treatment of private agreements to bargain or consider under contract law.

${ }^{146}$ The change in burden of proof might, of course, lead to the more frequent denial of summary judgment, but by refocusing on burdens of proof, the proposed approach avoids the problem of inappropriate denials of summary judgment that could arise under current ADA law.

${ }^{147}$ I intentionally omit FMLA interference claims, as where an employer refuses to provide required leave or to reinstate a returning employee. While courts have sometimes expressed confusion over the allocation of proof in such cases, the better understanding is 
the case of the FMLA, where an employer violates the statutory interactive process obligation described above, the court would assume that the employer unlawfully took account of the employee's use of leave or invocation of rights in rendering a temporally connected adverse employment decision. Similarly, in the case of a discriminatory failure to accommodate claim, the court would assume that an employer who failed in good faith to consider the employee's request was motivated at least in part by gender or pregnancy. The burden of proof in such situations would be on the employer to establish that its asserted nondiscriminatory rationale was in fact the reason (or a sufficient reason) for its decision. Such an approach would be justified on the assumption that an employer is less likely to be influenced by stereotype and more likely to voluntarily engage in viable workplace restructuring where an honest and objective interactive process occurs.

A recent case concerning the enforceability of an arbitration agreement in the context of an FMLA dispute provides a useful illustration of a procedural breakdown in which a presumption and burden shift could apply. In Darrah $v$. Friendly Ice Cream Corp., the plaintiff was an assistant manager who took FMLA leave because of a high-risk pregnancy. ${ }^{148}$ Darrah alleged that upon returning from leave, her hours were reduced and she was demoted to a waitress position. ${ }^{149}$ The parties had signed an arbitration agreement that provided for a two-step dispute resolution process; it required both parties to attempt to resolve any claims through the "Company Open Door Policy" and, in the event of failure, by binding arbitration. ${ }^{150}$

Within a week of her return to work, Darrah invoked the open-door policy and requested a meeting with the general manager about her post-leave work status. ${ }^{151}$ According to the plaintiff, the manager laughed and said that Darrah was "being hormonal."152 When she went up the chain of command to her district manager, Darrah was rebuffed again and told that the matter was within the exclusive control of the store manager. ${ }^{153}$

Upon the employer's motion to compel arbitration, the court noted that, by its terms, the parties' agreement to arbitrate was conditional on the failure of the open-door policy. ${ }^{154}$ It went on to explain that an open-door policy is understood to entail an "interactive... process" in which a supervisor and the aggrieved

that the burden is on the employer to justify its actions once the plaintiff shows that she was a qualified employee and that leave or reinstatement was denied. See supra note 80 and accompanying text. If that is the case, no burden shift would be necessary.

148328 F. Supp. 2d 319, 319-20 (N.D.N.Y. 2004).

${ }^{149}$ Id. at $320-21$.

${ }^{150} \mathrm{Id}$. at 320 .

${ }^{151} \mathrm{Id}$. at $320-21$.

${ }^{152} I d$. at 321 .

153 Id.

${ }^{154} \mathrm{Id}$. at 322. 
employee "attempt[] in good faith to resolve the dispute." 155 While Darrah fulfilled her duty to engage in that process, the defendant did not. ${ }^{156}$

Given the context of the case, the court used the employer's lack of good faith as a basis for finding the plaintiff's claim to be non-arbitral: the promise to arbitrate failed due to the non-fulfillment of the condition precedent that both parties engage in the open-door policy. ${ }^{157}$ In the context of the two-part proposal advocated in this Article, the employer would be held to have violated its obligation to engage in an interactive process with Darrah upon her return from leave. As described above, statutory fees would attach for the violation. In addition, and perhaps more significantly, the employer would also bear the burden of proof on the related retaliation claim. Most likely that claim will hinge on a factual assessment of motive, specifically whether the employer's demotion decision was based on the plaintiff's FMLA leave or was due to some legitimate non-discriminatory reason, for instance, a business decision to eliminate the plaintiff's former position. ${ }^{158}$ Current doctrine would require Darrah to prove that her leave was the reason, or at. least a motivating reason, for the employer's action. ${ }^{159}$ Under the proposed approach, however, the procedural violation shifts the burden of proof of motive to the defendant; the employer must demonstrate

${ }^{155} \mathrm{Id}$.

${ }^{156} \mathrm{Id}$.

${ }^{157}$ Id. The court also noted that the employer's failure to participate in the open-door policy could be read as evidence that it did not consider FMLA claims to be within the scope of the arbitration agreement, "[o]therwise it would have made at least some attempt to resolve plaintiff's grievance." Id. at 323.

${ }^{158}$ I analyze Darrah's claim as falling within the anti-retaliation provision of the FMLA because that is how it is presented in the opinion. See id. at 319. However, based on the facts, Darrah could have framed her case as a failure to reinstate under the statute. See 29 U.S.C. $\$ 2614$ (a)(1)(A) (2006). While many courts do not distinguish between these two types of claims, it is probably more appropriate, and more favorable to the plaintiff, to analyze factual scenarios such as this one under the failure to reinstate provision of the statute. See supra note 80 . In either case, however, a legitimate elimination of a position would constitute a defense to liability. See 29 U.S.C. § 2614(a)(3) ("Nothing in this section shall be construed to entitle any restored employee to ... any right, benefit, or position of employment other than any right, benefit, or position to which the employee would have been entitled had the employee not taken the leave"); 29 C.F.R. § 825.216 (2006) ("An employee has no greater right to reinstatement or to other benefits and conditions of employment than if the employee had been continuously employed during the FMLA leave period.").

${ }^{159}$ Those courts that have addressed the issue have generally assumed that the mixedmotive framework set forth by the Supreme Court in Desert Palace v. Costa, Inc., 539 U.S. 68 (2003), is applicable to FMLA claims. See, e.g., Richardson v. Monitronics Int'l, Inc., 434 F.3d 327, 334-35 (5th Cir. 2005); Gibson v. Louisville, 336 F.3d 511, 513-14 (6th Cir. 2003); Gonzalez v. Minneapolis, 267 F. Supp. 2d 1004, 1010 (D. Minn. 2003). 
that its decision was justified by legitimate reasons not pertaining to the employee's pregnancy or her invocation of FMLA rights. ${ }^{160}$

The core purpose of these doctrinal changes would be to encourage compliance with the proposed interactive process amendment with the hopes that good process can lead to voluntary accommodation. However, there is also reason to think that the presumption of liability is appropriate in its own right. It would not be unusual for an employer to take a worker's extended leave into account in making a subsequent layoff or demotion decision, and perhaps most would not consider their action to be discriminatory. For instance, as a result of an employee's extended absence the employer might realize that the employee's services were not essential, or in the case of the need to reduce or demote staff, the employer might select the employee who is most frequently absent in order to preserve office morale. ${ }^{161}$ While there is arguably no legitimate reason to mistreat employees purely on the basis of a protected characteristic like race or sex, there are often business reasons to treat employees requiring leave differently from mainstream workers. Thus, it might be appropriate as a general matter to lighten the burden on FMLA plaintiffs seeking to establish that retaliatory considerations played a role in an adverse employment decision.

It is also possible that burden shifting can increase the likelihood of capturing refusals to accommodate that are influenced by cognitive bias. Illustration 1 in Part II above involving the pregnant truck driver who was denied a lifting restriction, provides an example of a situation in which latent biases probably played at least some part in the decision. In Walker v. Fred Nesbit Distributing Co., the case on which the fact pattern is based, the employer defended its refusal to accommodate by attacking the relevance of the male comparators the plaintiff introduced, whose injuries had been previously accommodated. ${ }^{162}$ The employer asserted that because the male employees had been injured on the job and were receiving workers' compensation, it made business sense for it to allow them lifting restrictions so that it would receive at least some labor in return for paying them their statutory benefits. ${ }^{163}$ That rationale was ultimately accepted by a jury that found against Walker on her pregnancy discrimination claim. ${ }^{164}$

${ }^{160}$ This burden of proof would be in addition to the burden already placed on a defendant in a mixed-motive case to prove that it would have made the same decision about the plaintiff's employment absent any illegal considerations. See 29 U.S.C. $§ 2000 \mathrm{e}-$ $5(\mathrm{~g})(2)(\mathrm{B})$; Costa, 539 U.S. at 94-95. In other words, in mixed-motive cases the employer would have to prove both that its asserted justification was in fact a cause of its decision and that the justification was a sufficient basis for the decision. See generally Martin J. Katz, The Fundamental Incoherence of Title VII: Making Sense of Causation in Disparate Treatment Law, 94 GEO. L.J. 489 (2006).

${ }^{161}$ See, e.g., Rice v. Sunrise Express, Inc., 209 F.3d 1008, 1011 (7th Cir. 2000) (noting that the employer told the plaintiff she was selected for layoff because she was "already off").

${ }^{162} 356$ F. Supp. 2d 964, 966 (S.D. Iowa 2005).

${ }^{163}$ Id.

${ }^{164}$ Id. at 968. 
However, an informed examination that keeps in mind the subtle effects of cognitive bias suggests the employer's actions were suspect, particularly in light of surrounding facts. Walker produced evidence that despite the employer's alleged distinction, it had on previous occasions accommodated non-work related injuries for male employees, a fact that the employer conceded. ${ }^{165}$ The company alleged that it had recently made a change in policy that prohibited accommodation of nonworkplace injuries, but it was unable to produce any written documentation of the change, nor could it cite a date on which the changed policy had taken effect. ${ }^{166}$ Finally, and perhaps most importantly, Walker was the only woman truck driver employed at the company. ${ }^{167}$ Under the circumstances, it is easy to imagine that the employer's decision not to accommodate Walker was influenced, at least in part, by an implicit assumption that a woman, particularly a pregnant one, should not be driving a truck. Indeed, the premise of the employer's defense- that differences in the type and cause of one's disability merit differential treatment ${ }^{168}$ - suggests that the employer could not visualize a pregnant woman as similarly situated to a man who had injured himself in a workplace accident or in an aggressive game of football over lunch.

\section{Conclusion}

Recent developments in discrimination jurisprudence suggest the potential for a viable organizational justice approach to redressing the diminished employment quality of working caregivers. In both sexual harassment and disability law, courts have recognized the role employers play in responding to discrimination in assessing substantive statutory liability. Such moves implicitly recognize the core problem underlying second-generation disparities in employment quality-that historical segregation of non-traditional workers, as well as lingering misperceptions and stereotypes, perpetuate a status quo in which non-traditional workers are excluded. An employer who makes proactive efforts and engages with its non-traditional employees is likely to achieve a more inclusive workplace. Thus, while courts have not yet realized a fully effective way of providing incentives for such behavior, one can derive from their initiatives a blueprint for a meaningful approach to caregiver exclusion. Through a statutory interactiveprocess obligation, enforced through a monetary penalty and coupled with a judicially created burden shift, the law can reframe liability for second-generation disparities as a problem of encouraging positive behavior rather than searching out traditional indicia of fault.
${ }^{165} \mathrm{Id}$. at 970 .
${ }^{166} \mathrm{Id}$. at $970-71$.
${ }^{167}$ Id. at 965.
${ }^{168} \mathrm{Id}$. at 966. 


\section{THE CASE FOR PROCESS: THEORETICAL FOUNDATIONS AND EMPIRICAL SUPPORT FOR AN ORGANIZATIONAL JUSTICE APPROACH}

A core argument of this Article is that the use of internal processes can help employees to successfully effectuate accommodations that serve their needs and at the same time serve the legitimate business concerns of their employers. As a corollary, this Article suggests that the law should provide incentives for accommodation by requiring and protecting private procedural initiatives by the employers. This section traces the theoretical foundation for such an approach and explores whether such an approach is likely to be effective, given the absence of an expansive accommodation mandate addressing working caregivers and the risk that employers will manipulate a purely procedural initiative.

\section{A. A "Second-Generation" Response to "Second-Generation" Employment Disparities}

The organizational justice model proposed in this Article dovetails two related trends in employment discrimination scholarship and the broader field of regulatory theory. The idea of assessing employer liability for discrimination based on its internal practices rather than specific external standards coincides with scholarly attention to the way second-generation employment exclusion is organizationally facilitated and the recognition that organizationally specific responses are needed. ${ }^{169}$ At the same time, the concept of legally facilitated, but voluntarily created, solutions to such problems resonates with an emerging regulatory philosophy that combines public oversight with private initiatives to achieve a cost-effective means of legal enforcement. ${ }^{170}$ Drawing on literature from both fields, this section contends that, properly conceived, an organizational justice approach to discrimination liability can inspire narrowly tailored, employer-driven solutions to exclusion; revamp the intent inquiry in assessing legal liability; and impose a necessary check on voluntary initiatives of employers that might not

169 See, e.g., Green, supra note 1, at 108-11 (providing examples of how work structure and institutional practices exclude non-traditional workers); Sturm, supra note 1, at 468-75 (describing how subtle perceptions and patterns of interaction intersect with ordinary workplace dynamics to exclude women and minorities).

${ }^{170}$ See Estlund, supra note 14, at 377-83 (calling for system of monitored employer self-regulation of labor standards, such as work safety regulations); Orly Lobel, Renew Deal: The Fall of Regulation and the Rise of Governance in Contemporary Legal Thought, 89 MINN. L. REV. 342, 371-404 (2004) (delineating the organizing principles of an emerging "renew deal" governance model that involves collaboration and partnership between regulators and private actors); Sturm, supra note 1, at 553-67 (describing a system of "dynamic problem solving," combining the roles of the judiciary, individual change agents, and mediating institutions). For background on the emerging theory of new regulation outside of the specific employment context, see generally IAN AYRES \& JOHN Braithwaite, Responsive Regulation: Transcending the Deregulation Debate (1992). 
otherwise serve the goals of discrimination law. Ideally, it can also engender grassroots support for transformative workplace initiatives by treating employers (and workers) as partners in the process of eradicating second-generation exclusion.

\section{Organizational Justice as Tailored Regulation}

A common theme in recent commentary on regulating the workplace is the need for alternatives to proscriptive rule-oriented efforts in responding to secondgeneration exclusion, as well as improving working conditions more generally. ${ }^{171}$ The disenchantment with "command and control"172 approaches to directing employer conduct recognizes both the complexity of organizational life and the inherent limitations of top-down approaches in targeting context-specific behavior. ${ }^{173}$

Major settlements reached in recent discrimination class action suits illustrate the potential for narrow, yet flexible approaches to redressing disparities in employment quality. In litigation against industry giants such as Home Depot, American Express, and Abercrombie \& Fitch, plaintiffs have challenged institutional practices, including informal assignment systems, inconsistent allocation of training, and subjective promotion and hiring procedures that have the effect of excluding women and minorities. ${ }^{174}$ In settling these cases, plaintiffs'

${ }^{171}$ See, e.g., Green, supra note 1, at 144-52 (exposing the need to reframe traditional discrimination strategies to capture discriminatory workplace dynamics); Sturm, supra note 1, at 475-79 (describing the limits of a rule-enforcement approach in addressing secondgeneration discrimination); $c f$. Estlund, supra note 14, at 323 (noting the practical limitations of an individual litigation model and government agency supervision in enforcing labor standards and civil rights); Orly Lobel, Interlocking Regulatory and Industrial Relations: The Governance of Workplace Safety, 57 ADMIN. L. REv. 1071, 1079-86 (2005) (describing the limited ability of government regulators to adequately inspect worksites and deter noncompliance in the work safety arena).

${ }_{173}^{172}$ Estlund, supra note 14, at 322.

173 See, e.g., Tristin K. Green, Targeting Workplace Context: Title VII as a Tool for Institutional Reform, 72 FORDHAM L. REV. 659, 671-72 (2003); Sturm, supra note 1, at 465-79. One analogous example of this type of regulatory failure, and one of particular consequence to caregivers, is the requirement of time and-a-half compensation for work in excess of forty hours per week under the Fair Labor Standards Act. This fixed mandate precludes employer and employees from negotiating alternate arrangements, like "comp time" in lieu of overtime pay, that might be more desirable to both parties. See Cynthia L. Estlund, Between Rights and Contract: Arbitration Agreements and Non-Compete Covenants as a Hybrid Form of Employment Law, 155 U. PA. L. REV. 379, 442-43 (2006) (suggesting the possible conversion of mandatory overtime pay to a "conditionally waivable" right which could be exchanged for "comp time", subject to the assurance that such time would accrue at the same time-and-a-half rate as overtime pay and would be available for use at times beneficial to workers).

${ }^{174}$ See Green, supra note 173, at 682-87 (discussing key settlements in cases against Coca-Cola and American Express, among others); Sturm, supra note 1, at 509-19 
counsel have succeeded in obtaining commitments to institutional reform in addition to monetary relief for victims. Thus, in the Home Depot litigation, for instance, the defendant agreed to establish a database that systemized selection of job applicants for interviews, require a minimum of three applicant interviews for each position, and establish structured interview questions. ${ }^{75}$ Home Depot also agreed to internally monitor the system and to report regularly to class counsel. ${ }^{176}$ While the value of these concessions should not be overstated, such commitments arguably go beyond what the law requires and what a judge would likely have awarded had these cases succeeded at trial. ${ }^{177}$

The question is: by what means can the current legislative regime enable more widespread adoption of such measures ex ante? It is extraordinarily difficult to envision an appropriately responsive method of direct regulation. Employers are a diverse group with different infrastructures, hierarchies, and cultures, as well as different degrees of heterogeneity in their workforce. ${ }^{178}$ In addition, such organizational characteristics are often in flux. As companies strive to maintain their competitiveness, they must often accommodate rapid changes in their product and market bases, requiring them to make frequent, nimble adjustments in their labor pool and hiring practices. ${ }^{179}$ At the same time, the particular problem of second-generation exclusion is itself elusive, arising through the joint operation of social psychology and particular organizational practices. In this environment, traditional rulemaking in the form of new legislation or expanded liability is unlikely to achieve the requisite, and to some extent conflicting, degrees of specificity and flexibility needed to defeat subtle biases and effect more inclusive work practices. ${ }^{180}$

(discussing the settlement of a Home Depot class action suit brought by female employees).

${ }^{175}$ See Green, supra note 173 , at 682-86; Sturm, supra note 1, at 513-14.

${ }^{176}$ See Green, supra note 173, at 682-86; Sturm, supra note 1, at 517.

177 My purpose here is not to applaud any particular settlement outcome, and admittedly, there is some question as to whether the terms of such agreements have achieved their intended results in particular cases. See, e.g., Michael Selmi The Price of Discrimination: The Nature of Class Action Employment Discrimination Litigation and its Effects, 81 TEX. L. REV. 1249, 1286-89 (2003) (critically considering the Home Depot settlement). Rather the point is to showcase the diversity of results that flows from collaborative problem-solving, which, in the case of a procedural mandate, would not replace or preclude civil judgments on other substantive claims.

${ }^{178}$ See Lobel, supra note 170, at 359 (describing "diversity of market" on which legal reform must be brought to bear).

179 I have described this phenomenon elsewhere at length, as have others. See generally CAPPELLI, supra note 82, at 59-64; Arnow-Richman, supra note 82, at 11981202; Green, supra note 1, at 104-08; Stone, supra note 82, at 539.

${ }_{180}$ See Cary Coglianese \& David Lazer, Management-Based Regulation: Prescribing Private Management to Achieve Public Goals, 37 LAW \& SoC'Y REv. 691, 704-05 (2003) (asserting that "a strong theoretical justification exists for management based regulation" over traditional regulatory forms where there is "industry heterogeneity" and it is difficult to "identify linkages between actions and outputs" as is necessary to create standards for 
In contrast, the protocols that emerge in class actions settlements arise from organic problem solving, the result of situation-specific issues and jointly developed solutions. The key then is replicating this environment, absent the threat of pending litigation, with alternative incentives. In the scholarship of governance and regulatory theory, commentators have elaborated on how new forms of regulation can leverage industries' willingness to self-police and the expertise of institutional actors to achieve well-tailored standards and greater rates of compliance. ${ }^{181}$ One notable illustration from the employment context that has received scholarly attention is the development of cooperative enforcement strategies within the Occupational Safety \& Health Administration ("OSHA"). ${ }^{182}$ These include a federal program that offers reduced government oversight to employers that demonstrate the ability to comply with and maintain safety standards and a variety of state initiatives that require employers to create their own safety and compliance plans. ${ }^{183}$ What is needed is an analogous approach to the implementation of civil rights principles, broadly construed. Already scholars have called for leveraging the expertise of employer agents ${ }^{184}$ and incorporating third-party actors in developing a suitable response to second-generation exclusion. ${ }^{185}$ The anticipated result is more efficient, responsive elaboration of legal standards and better rates of compliance. ${ }^{186}$

reducing undesirable outcomes); Sturm, supra note 1, at 475 ("Rules developed externally... cannot adequately govern the range of circumstances implicated by the general principle of nondiscrimination .... Any rule specific enough to guide behavior will inadequately account for the variability, change, and complexity characteristic of second generation problems.").

${ }^{181}$ See generally AYRES \& BRAITHWAITE, supra note 170, at 101-33.

${ }^{182}$ Coglianese \& Lazer, supra note 180, at 698-99; Estlund, supra note 14, at 343-47; Lobel, supra note 171, at 1104-08.

${ }^{183}$ Coglianese \& Lazer, supra note 180, at 698-99 (describing OSHA's adoption of a "process safety management" program for highly hazardous substances under which firms must implement a risk assessment process and develop, assess, update, and certify operating procedures that target the elimination of those risks); Lobel, supra note 171, at $1104-08$.

${ }^{184}$ See Sturm, supra note 1 , at 564-66 (calling for greater attention to the problemsolving function of "individual change agents" within firms, including in-house attorneys and human resource professionals, in addressing second-generation bias).

${ }^{185}$ See id. at 566 (speculating a role for mediating institutions, including the EEOC, employee organizations, and insurance agencies, in encouraging information sharing and self-evaluation with respect to second-generation work problems).

${ }^{186}$ The achievements of second-generation compliance strategies in the work safety context have been widely lauded. See Lobel, supra note 171, at 1128-36 (noting successful rates of compliance and management benefits occasioned by enhanced worker participation). Of course, the analogy between regulation of workplace safety through agency rulemaking and regulation by civil rights legislation enforced almost exclusively by individual lawsuits is a loose one. However, the successes in the former context are encouraging. 
Such approaches ultimately are consistent with the natural patterns of law and governance. From the dichotomous tension between substantive regulation and deregulated markets, an organizational justice approach emerges as a possible middle ground. ${ }^{187}$ Most scholars have long given up on the idea that market forces alone will weed out animus-based discrimination, let alone the persistent forms of exclusion that for all appearances seem natural or efficient. ${ }^{188}$ Yet, neither new lawmaking nor a heightened degree of judicial activism is likely to be forthcoming, let alone equal to the task. An organizational justice approach avoids the political divisiveness of traditional legal responses as well as the inherent limitations of haphazard litigation and judicial enforcement. The upshot is better tailored results brought about by engaging the people affected (employers and workers) in a collaborative process that responds to particular problems dynamically.

\section{Organizational Justice as Consensus Builder}

In the same vein, incentivized organizational justice can build consensus by incorporating employers in the standard-setting and compliance process. The approach treats employers as experts in the needs of their organizations, the limits of their practices, and the best means of addressing second-generation exclusion within those constraints. ${ }^{189}$ It seeks to transform the workplace incrementally by facilitating communication and information sharing between workers and employers and fostering buy-in and commitment on both sides.

Involving employers in a legitimate interactive process that both imposes limits and respects managerial discretion enables organic, non-threatening institutional change and learning. Traditional rulemaking presupposes an adversarial relationship between worker and employer that is arguably outmoded and often counterproductive. ${ }^{190}$ While the business case for flexible work and other employee-friendly management practices may be somewhat overstated, ${ }^{191}$ there are

${ }^{187}$ See Lobel, supra note 170, at 443 (describing the "renew deal" governance model as a "third way between state-based, top-down regulation and a single-minded reliance on market-based norms").

${ }^{188}$ See, e.g., Arnow-Richman, supra note 10, at 378-86 (describing how the move from internal to external labor markets provide disincentives for some forms of voluntary accommodation); Selmi, supra note 4, at 745-50 (noting the persistence of "rational discrimination" with respect to caregiving).

${ }^{189}$ See, e.g., Coglianese \& Lazer, supra note 180, at 695 (noting that managementbased regulation, in which firms engage in their own planning and internal rulemaking efforts, "place responsibility for decisionmaking with those who possess the most information about risks and potential control methods").

${ }^{190}$ See Lobel, supra note 170, at 376-77 (noting that a regulatory model that involves top-down decision making by experts "promotes adversarial relations, mutual distrust, and conflict").

191 See Arnow-Richman, supra note 10, at 378-81 (suggesting that individual instances of employers voluntarily implementing expansive family-friendly policies are the exception rather than the rule, and that wide-scale adoption of policies to serve business interests in worker loyalty and retention are unlikely to be forthcoming). 
certainly synergies that can be exploited, provided the law serves as a facilitator. ${ }^{192}$ The point is that such results, however beneficial, are not likely to be achieved wholly through market forces. Rather, a necessary precondition is the creation of a safe forum in which to identify and explore change. ${ }^{193}$ That is unlikely to happen where an expanded liability regime unilaterally imposes additional duties on employers and management responds by steeling itself against liability. Indeed top-down approaches and the resistance they are likely to occasion are antithetical to the inclusive culture second-generation reform efforts seek to foster.

At the same time, organizational justice approaches can lay the foundation for transformative lawmaking. External laws that strongly conflict with institutional norms run the risk of being captured by the entities they seek to regulate. ${ }^{194}$ Employers may interpret and implement rules in ways that suit their own ends, infusing them with managerial values that undermine their force and purpose. ${ }^{195}$ Courts may be influenced by such behavior or their own normative dissonance, resulting in judicial retrenchment. ${ }^{196}$ At least one way of avoiding such pitfalls is to slowly develop normative support for transformative law through inclusiveness. Social science research has suggested that novel legislation is more likely to succeed where the regulated community is involved in its creation, interpretation, and application. ${ }^{197}$ An organizational justice approach embodies this idea insofar as

${ }^{192}$ See infra Part IV.B.2.

${ }^{193}$ See Coglianese \& Lazar, supra note 180, at 702-03 (noting the need for compelled planning and risk assessment by employers despite the fact that management and societal interests often overlap, because employers are likely to resist investing in identifying synergies for fear they will bear significant costs that will not be justified by significant private gains).

194 See Krieger, supra note 13, at 497 (describing the problem of "socio-legal backlash" that occurs "when the application of a transformative legal regime generates outcomes that conflict with norms and institutions to which influenced segments of the relevant populace retain strong conscious allegiance").

195 See, e.g., Lauren B. Edelman \& Mark C. Suchman, When the "Haves" Hold Court: Speculations on the Organizational Internalization of Law, 33 LAW \& SOC'Y REV. 941, 961-80 (1999); see infra Part IV.A.5.

${ }^{196}$ See, e.g., Arnow-Richman, supra note 10, at 362-73 (describing judicial resistance to expansive interpretation of ADA and FMLA accommodation mandates stemming from entrenched notions of formal equality); Bagenstos, Structural Turn, supra note 96 at 35 (suggesting that courts are incapable of evaluating proactive employer conduct absent a shared normative understanding of what constitutes actionable second generation discrimination); Travis, supra note 5, at 21-36 (describing judicial misunderstanding of essential job functions due to the "full-time face-time norm"). See generally Krieger, supra note 13, at 486 (describing how judges' conscious or unconscious allegiance to traditional values may constrain their interpretation of transformative law, resulting in rules that increasingly come to resemble the norms and systems they were designed to displace).

197 See Krieger, supra note 13, at 498-503 (describing the ultimate success of the Santa Cruz appearance ordinance, as compared to the ADA, where the ordinance applied to an insular community and was enforced through a mediation process that encouraged understanding of disputants' competing normative perspectives). 
employers play a critical role in defining and implementing more inclusive work practices. In addition to achieving individual accommodation for some workers, the process enables organic cultural change and norm elaboration that may yield a foundation for broader rulemaking. In this way, an organizational justice approach can serve as a necessary preliminary step in achieving the broad-based support required for effective accommodation mandates or substantive benefits laws.

\section{Organizational Justice as Democratic Agent}

Of equal if not greater importance than the role of employers, is the organizational justice vision of worker voice. The approach does not simply provide incentive for positive managerial action, but specifically rewards action taken on the basis of and in response to a dialogue with affected workers.

This is critical in several respects. In a post-union world where traditional representation is largely absent, employees often have no voice in basic compensation and benefits decisions, let alone specific workplace policies. Almost nothing in our arsenal of substantive rights laws addresses this problem. ${ }^{198}$ In contrast, an organizational justice approach-one that requires employers to communicate with their workers and gives them an incentive to listen-reflects a shift toward greater employee participation in the terms of their employment. Whereas employees are generally the objects of employers' unilateral implementation of legal rules, the organizational justice model views them as active, participatory citizens in their employers' compliance practices and decision-making process. ${ }^{199}$

In this way, the organizational justice approach coincides with other trends in the contemporary workplace. While employees may have limited say in the terms and conditions of employment, they are increasingly participating in the business and production decisions of their employers. In many companies, flattened hierarchies have replaced traditional advancement and decision-making ladders, and collaborative teamwork has eclipsed supervisory relationships. ${ }^{200}$ In these environments, employees are viewed as stakeholders in the success of the business and are expected to act as entrepreneurs in initiating and developing novel ideas. ${ }^{201}$ It is a short stretch from this model of fostering and managing human capital within firms to engaging employees in decisions about their own employment terms. Thus, organizational justice approaches can leverage the emerging model of decentralized, democratic business decision making to include employees as

198 See Estlund, supra note 14, at 326 (asserting that contemporary statutes and common law doctrines governing terms and conditions of employment "do nothing to fill the vacuum - the democratic deficit-left by the decline of unionization and collective bargaining").

${ }^{199}$ See Lobel, supra note 170 , at 371-76.

${ }^{200}$ See CAPPELLI, supra note 82, at 59-64; Arnow-Richman, supra note 82, at 11981202; Green, supra note 1, at 98-104; Stone, supra note 82, at 533-35.

${ }^{201}$ See CAPPELLI, supra note 82, at 59-64; Arnow-Richman, supra note 82, at 11981202; Green, supra note 1, at 101; Stone, supra note 82, at 533. 
experts and collaborators in the various ways their jobs can and should be packaged and performed.

Finally, while organizational justice is hardly a substitute for traditional bargaining, it may create a framework for collective action. Research suggests that even the mobilization of individual rights is a social process; the act of naming a right as such derives in part from the aggrieved individual discussing his or her situation with others, recognizing shared experiences, and learning about the law. ${ }^{202}$ In the workplace, such interactions between employees can lead to a culture where unilateral employer action is questioned and even delegitimized. ${ }^{203}$ As employees become aware of the legal dimensions and commonality of their grievances, they may be more likely to view their situation in the context of a broader rights discourse and more inclined to engage in explicitly concerted action. ${ }^{204}$

\section{Organizational Justice as Liability Proxy}

Incentivized organizational justice also offers a concrete alternative to animus-based intent as the touchstone for discrimination liability. A conceptual challenge to the expanded use of discrimination law is the absence of fault, as traditionally understood, in the behavior that perpetuates disparate employment quality. In the context of cognitive bias, the mental schemas that color managerial decision making operate subconsciously. ${ }^{205}$ The cognitive categories and associations that lead to skewed results may be tied at some level to prejudicial assumptions or even animus, but their operation is by definition unintentional. In contrast, where exclusion results from structural impediments, such as job design or organizational norms, the workplace conduct or circumstances might fairly be described as intentional, but that intent is morally benign. If an employer places a fifty-pound lifting requirement on its truck drivers or demands full-time, in-office work hours from its attorneys, the employer is certainly intending to exclude a subset of workers, but it is not motivated by animus toward a protected class.

Of course, it is by no means clear that prejudicial motive is a required predicate to liability under existing law, and certainly there are many functional

${ }^{202}$ See ENGEL \& MUNGEL, supra note 141, at 78-80, 90-98; Catherine Albiston, Bargaining in the Shadow of Social Institutions: Competing Discourses and Social Change in Workplace Mobilization of Civil Rights, 39 LAW \& SOC'Y REV 11, 27-28 (2005).

${ }^{203}$ See Albiston, supra note 202, at 43 (finding in a study of employees who informally challenged employer decisions about family medical leave that "the existence of legal rights prompted [employees] to talk with others about their experiences in the workplace, to discuss whether their employer's actions were legitimate, and in some instances, to band together to resist their employer's reinterpretation of [the law]").

${ }^{204}$ See id. at 28 ("[I]nformal rights mobilization through workplace interactions ... can also encourage workers to conceptualize their problems as part of a broader system of power and control .... In some instances ... sharing information can create a collective framework for interpreting opposition to rights.").

${ }^{205}$ See, supra, II.B.1.b. 
and normative arguments for treating "unintentional" and "intentional" discrimination as equivalents. ${ }^{206}$ However, accepting those premises does not resolve the challenging question of how to determine what unintentional conduct and which neutral structures should be actionable. In practice, liability under existing antidiscrimination and accommodation laws turns on proof structures that are at least loosely tied to the animus and intent constructs. A showing of disparate treatment requires that a jury find a discriminatory motive, historically understood as a conscious act; while avoiding liability for failure to accommodate under disability law turns on the employer's rational (that is, cost-driven rather than animus-based) justifications for its decision. ${ }^{207}$ Infusing such concepts with an appreciation for the exclusionary effects of morally benign conduct may prove more difficult than theorizing a rationale for doing so.

For instance, some argue that placing cognitively biased decision making within the realm of ordinary disparate treatment law will not achieve the intended result of shifting the cost of unconsciously inflicted harm from employees to employers. ${ }^{208}$ Because the operation of bias is difficult to detect, courts are likely to be poor judges of whether a particular decision has been unlawfully tainted, resulting in employers being routinely over- or under-charged for the biases in which they engage. ${ }^{209}$ In addition, because such biases are difficult to control, employers may act inefficiently in responding to the risk of liability, for instance,

${ }^{206}$ See, e.g., Bagenstos, supra note 79, at 837-38 (suggesting that antidiscrimination law aims not so much at eradicating animus as eliminating exclusion, as evidenced by existing prohibitions on "rational" discrimination); Jolls, supra note 52, at 651-52 (suggesting that antidiscrimination disparate impact theory and accommodation requirements are functionally equivalent; in both cases employers must engage in affirmative behavior to account for the disparate effects of neutral practices); Selmi, Disparate Impact Theory, supra note 44 at 760 (suggesting that the historical equating of disparate treatment liability with proof of animus or motive was unnecessary and "borne out of a strikingly limited definition of intent"); Wax, supra note 21, at 1138-39 (noting that intent can be understood as both scienter and as a causal link between a mental influence and a particular decision).

${ }^{207}$ This discussion is not intended to suggest that discrimination law, as currently applied, contains no hook for redressing "unintentional" conduct, for indeed there is some room within existing law to capture unconscious behavior. See Hart, supra note 3, at 750; Michael Selmi, Proving Intentional Discrimination: The Reality of Supreme Court Rhetoric, 86 GEO. L.J. 279, 285, 335-38 (1997); Wax, supra note 21, at 1149-50 (noting that while the McDonnell Douglas framework is "formally at odds with liability for unconscious forms of disparate treatment... there inevitably will be some degree of overlap in the evidence that tends to prove 'pretext' and the evidence that tends to prove unconscious bias"). Instead, the assertion is that because such conduct is not the principle wrong that the law is designed to address, existing doctrine does not supply a useful framework for distinguishing between conduct and circumstances that should trigger liability and those that should fall outside of the legal apparatus. See Bagenstos, Structural Turn, supra note 96 at 35.

${ }^{208}$ See Wax, supra note 21 , at 1149-50.

${ }^{209} \mathrm{Id}$. 
by categorically reducing adverse actions taken against protected employees or adopting affirmative-action programs that eliminate statistical imbalances without actually diminishing the effects of cognitive bias. ${ }^{210}$

An appropriate response to this problem, however, is not to ignore these harms, so much as to identify the circumstances under which they are most likely to occur, and restructure discrimination liability in ways that encourage employers to reevaluate and disable the structures that perpetuate bias. Professor Tristin Green's work on structural discrimination and disparate treatment theory suggests as much. ${ }^{211}$ Drawing on social science evidence, ${ }^{212}$ Professor Green proposes holding employers liable in situations where their organizational practices and structures enable discriminatory race or gender bias. ${ }^{213}$ Importantly, liability under such an approach would be tied to the internal practices of the employer and be structured in ways that encourage employers to act proactively to prevent structural exclusion. Professor Green directs courts and litigants to look for proactive conduct, such as employer efforts to construct and monitor heterogeneous work groups and provide guidance and structure for decision making, which some research suggests can minimize the likelihood of stereotyping and bias. ${ }^{214} \mathrm{~A}$ finding of "unreasonable institutional enabling of discriminatory bias" would permit courts to order employers to implement such safeguards and create a presumption of liability in favor of individuals alleging harm. ${ }^{215}$

Of course, such a proposal is not without flaws, ${ }^{216}$ but it provides one example of how scholars have begun to reconceive discrimination law to reflect a better understanding of organizational dynamics and how they affect the employment quality of non-traditional workers. ${ }^{217}$ What it offers is an alternative to the intent/liability paradigm that has long been the centerpiece of discrimination jurisprudence. The goal is to provide impetus for structural change and problem solving while acknowledging there are organizational forces and individual

${ }^{210} \mathrm{Id}$.

${ }^{211}$ See Green, supra note 1, at 145 (suggesting that the law should focus on the employer's role in enabling the effects of latent bias in applying the disparate treatment framework).

${ }^{212}$ See id. at $96-99$.

${ }^{213}$ See id. at 93.

214 See id. at 147.

${ }^{215} \mathrm{Id}$. at 148 .

${ }^{216}$ For instance, it is not clear how in practice such a standard would distinguish between "unreasonable enabling" by the employer and benign complacency. See Bagenstos, Structural Turn, supra note 96 at 35 . Also potentially problematic is the prospect of injunctive remedies upon a finding of liability, which will doubtlessly prove difficult to delineate and enforce.

217 As another example, Professor Vicki Schultz has proposed a presumption of employer liability for sexual harassment where women are insufficiently represented in the workforce. See Vicki Schultz, The Sanitized Workplace, 112 YALE L.J. 2061, 2174-76 (2003). 
subconscious biases the employer does not control and for which it would not be appropriate to hold the employer liable. ${ }^{218}$

\section{Organizational Justice as Reality Check}

A final reason for the adoption of an organizational justice model is that private initiatives aimed at redressing discrimination already exist and are proliferating. As scholars have noted, companies have become increasingly reliant on internal professionals, such as in-house attorneys and human resource experts, to interpret and comply with the law in the face of legal complexity. ${ }^{219}$ Uncertainty and the threat of litigation have led such experts to put in place proactive procedures to prevent and correct conduct that may lead to a lawsuit. ${ }^{220}$ Thus, practices such as diversity training and anti-discrimination polices long predated the special status conferred on them by the Supreme Court's harassment jurisprudence.

In many instances, such initiatives can provide immediate and effective assistance to workers without the delay and costs associated with litigation. For example, there is reason to believe that despite pro-defendant ADA jurisprudence, many employer accommodation initiatives have helped workers with disabilities achieve some level of workplace integration. ${ }^{221}$ In addition, employer efforts to head off liability sometimes go beyond legal requirements to benefit groups not otherwise protected and attempt large-scale cultural changes at work. ${ }^{222}$ It is also likely that judicial consideration of employer corrective action in assessing hostile work environment liability has led at least some employers to create effective response protocols. Where prompt intervention by human resource professionals ends harassing behavior, both employer and employee are likely better off than if judicial intervention is required.

However, there is no reason to take on faith that private initiatives, developed and administered under the radar of traditional enforcement mechanisms, will be used appropriately for the benefit of those the law was designed to protect. ${ }^{223}$ Research shows that the way companies respond to and interpret legal directives

${ }^{218}$ See Green, supra note 1, at 149-50 (suggesting that a "structural account" of disparate treatment law would aim to "create incentives for problem solving within institutions without deligitimizing the task by holding employers liable for forms of discrimination over which they have no realistic means of control").

219 See Sturm, supra note 1, at 527-30.

${ }^{220}$ See Edelman \& Suchman, supra note 195, at 953-58; Estlund, supra note 14, at 335-38.

${ }^{221}$ See ENGEL \& MUNGEL, supra note 141, at 243-44; Befort, supra note 112, at $622-$ 28.

${ }^{222}$ See Estlund, supra note 14, at 334.

${ }^{223}$ As Professor Cynthia Estlund writes, in the context of enforcement of wage/hour and health/safety laws, self-regulation is either a boon or a bane depending on how the law responds to it. Id. at $321-23$. 
reflects managerial values, such as productivity and conflict avoidance. ${ }^{224}$ This can result in a culture of compliance that deviates in significant ways from the rule of law. For instance, Professor Vicki Schultz has demonstrated that employers widely misconstrue sexual harassment law as broadly prohibiting physical advances and other sexualized conduct, reflecting entrenched notions of the workplace as a rational space removed from emotional distractions. ${ }^{225}$ As a result, employers may fail to discipline hostile non-sexual behavior directed at women and ignore larger issues of inequality that allow such harassment to flourish. Indeed, allegations of "sexual harassment," misunderstood in this way, may ultimately be levied unfairly against workers engaged in legally permissible conduct, or worse, used as a pretext for discriminatory discipline or termination of workers deemed suspect. ${ }^{226}$

Thus, there is a risk that, absent meaningful oversight, private initiatives may evolve in ways that are divorced from or even counterproductive to the goals of the laws that spawn them. Once such initiatives become incorporated into the institutional culture, adulterated legal norms become the benchmark for evaluating conduct within that workplace. ${ }^{227}$ While that problem will not disappear under the proposed regime, the incentivized organizational justice approach calls for greater public examination of employer-sponsored initiatives than currently exists. The point is that deference to employer practices is a far cry from deregulation; external law remains relevant. Indeed, contemporary regulatory proposals that espouse institutional self-governance in other areas, such as workplace safety, incorporate checks and balances like independent monitoring and employee whistleblower protection. ${ }^{228}$ If liability (or litigation incentives) is linked to serious, searching review of the quality and effectiveness of employer practices, an organizational justice model can ideally flush out employers who intentionally flout the law, as well as more modest failures by well-intentioned employers, enabling more effective responses to workplace exclusion.

\section{B. Will it Work?}

Whatever theoretical support regulatory theory may provide to organizational justice principles generally, ultimately the critical question is whether the caregiving proposal developed in this Article can work in practice. There may be no way to truly test the proposal short of adoption, but both anecdotal and empirical evidence offer reason to be hopeful. In the United Kingdom, legislation

${ }^{224}$ See, e.g., Schultz, supra note 217, at 2090-94 (explaining how the proscription against workplace sexual harassment has been interpreted by employers as consistent with an ideal of a sanitized workplace focused on productivity and divorced from passion and emotion). See generally Lauren B. Edelman et al., Diversity Rhetoric and the Managerialization of Law, 106 AM. J. SoC. 1589 (2001).

${ }_{225}$ See Schultz, supra note 217, at 2103-19.

${ }^{226}$ See id. at 2119-31 (noting that charges of harassment are disproportionately levied against men of color and gay men).

${ }^{227}$ See Edelman et al., supra note 224, at 1589.

${ }^{228}$ See Estlund, supra note 14, at 393-94. 
providing caregivers with a procedural "right to request" flexible work hours, which offers a close parallel to the current proposal, has achieved initial success. ${ }^{229}$ In addition, evidence of past employer accommodation efforts in the United States, directed toward both caregivers and the disabled, suggests that companies are willing to provide some forms of accommodation voluntarily. ${ }^{230}$ Finally, a preliminary examination of organizational and social psychology studies offer reason to hope that workplace procedures developed in response to the current proposal will empower non-traditional workers and erode cognitive bias. ${ }^{231}$

\section{Lessons from the United Kingdom}

A number of European countries already have laws giving a degree of protection to workers seeking flexible work hours, or other changes in work schedule. ${ }^{232}$ One British initiative is notable for coupling an expansive view of flexible work with significant deference to the business interests of employers. Under the "flexible working" provisions of the Employment Act of 2002 (the "Act"), British employees with primary caretaking responsibility for a child under six years of age have a statutory "right to request" a flexible work arrangement. ${ }^{233}$ Flexible work includes anything that varies from the ordinary work patterns of the organization, including flextime, compressed hours, working from home, and job sharing, among others. ${ }^{234}$ While the employer has no obligation to adopt the proposal, the employer must seriously consider the request and, in the event the request is denied, justify its decision based on the needs of the business. ${ }^{235}$

This "soft touch" law, as its supporters have called it, doubtlessly triggers legitimate skepticism on the part of employee advocates and feminist legal scholars. ${ }^{236}$ On its face, the Act confers no substantive rights. An employee always has the ability to request changes in working conditions, and a law that places no obligation on the employer to accept the worker's proposal may seem a hollow

${ }^{229}$ See infra Part IV.B.1.

${ }^{230}$ See infra Part IV.B.2.

${ }^{231}$ See infra Part IV.B.2.

${ }^{232}$ See, e.g., Employment Act, 2002, c. 22, § 47 (Eng.), available at http://www.opsi. gov.uk.acts/acts2002/20022--f.htm (giving British parents of children under age six the right to request flexible work).

${ }^{233}$ Id. This includes an adoptive parent, guardian, foster parent, step-parent, or parenting partner. See Terms and Conditions of Employment, 2002, S.I. 2002/3236, I 3(1)(b) (U.K.). The right to request also applies to caretakers of disabled children up to age eighteen. Employment Act, 2002, c. 22, § 47.

${ }^{234}$ See U.K. DEP'T OF TRADE \& INDUS., FlEXIBLE WORKING: THE RIGHT TO REQUEST AND THE DUTY TO CONSIDER 9-10 (2003) [hereinafter RIGHT TO REQUEST].

${ }^{235}$ See ARIANE HEGEWISCH, CTR. FOR WORKLIFE LAW, EMPLOYERS AND EUROPEAN FLEXIBLE WORKING RIGHTS: WHEN THE FLOODGATES WERE OPENED 5 (2005).

${ }^{236}$ See Audio tape: The Family Squeeze Conference Series: Right to Request Flexible Work: U.K. Emerging Lessons, held by the Center for Law and Social Policy (Jan. 28, 2005), available at $\mathrm{http}: / / \mathrm{www}$.clasp.org/audio/012805.m3u. 
exercise. What makes the United Kingdom's "right to request" meaningful is its focus on the quality and fairness of the process by which such requests are proposed and reviewed. The law achieves this through a set of particularized steps with which each side must comply during the course of the application and consideration process. Upon receipt of a request for flexible work, the employer must meet with the worker face-to-face to discuss his or her application, after which the employer must respond within fourteen days. ${ }^{237}$ Although the employer has discretion to deny the request, it may do so only on the basis of specific cost or management conflicts. ${ }^{238}$ If the employer denies a request, the employee may appeal the decision internally, in which case the employer must meet with the employee again to discuss its decision and provide a second response. ${ }^{239}$ Should the employer fail to complete any of these steps, the employee may pursue a claim with the appropriate employment tribunal. ${ }^{240}$

This detailed legislative framework goes beyond the approach advocated in this Article, which permits employers to establish their own procedures, judged by a general standard of good faith. However, the U.K. law offers useful lessons on what fair process means and how procedural law can encourage constructive employer practices. Notably, the U.K. law explicitly anticipates and encourages cooperation: agency guidance on the law and its requirements addresses not only employer compliance, but employee obligations as well, prescribing "best practice[s]" for both camps. ${ }^{241}$ The assumption is that employers want to provide flexible schedules for their workers, but need a better understanding of their individual needs, as well as some creative insight, in order to find suitable ways of achieving that result. ${ }^{242}$ By establishing a formal procedure for lodging and responding to accommodation requests, the law aims to place both parties on the same side of the table where they can educate one another and engineer mutually beneficial solutions. ${ }^{243}$

To the end of shared responsibility, the Act carefully balances the obligations of the employer and employee. As with the interactive process under the ADA, it is the duty of the employee to come up with a proposal for flexible work and initiate the statutory procedure. This must be done in the form of a "carefully thought-out" written application to the employer, ${ }^{244}$ that takes account of how the proposal will impact the employer and how any negative effects might be eliminated or

${ }^{237}$ Terms and Conditions of Employment, 2002, ๆๆ 3(1), 4.

${ }^{238}$ Employment Act, 2002, c. 22, § 47.

${ }^{239}$ Terms and Conditions of Employment, 2002, ๆๆ 6, 8, 9, 10.

${ }^{240}$ Employment Act, 2002 , c. $22, \S 47$. Damages of up to eight weeks pay may be awarded. See id.

${ }^{241}$ See Right TO REQUEST, supra note 234 , at 2-4.

${ }^{242} I d$. at 2 (noting that "employers know that it makes good business sense to provide flexible working opportunities for their staff," but "[n]ot all employers are aware of the different ways to arrange work" to accommodate workers' needs).

${ }^{243} I d$. (suggesting that the request process "facilitate[s] discussion and enables both parties to gain a clear understanding of each other's thinking").

${ }^{244}$ Id. 
addressed. ${ }^{245}$ This requirement not only prevents facially unreasonable requests, it sets the stage for constructive discussions between the parties and shared respect for their competing concerns. In effect, the Act treats the employee as having a stake in and responsibility for the business as a whole when making a request. For instance, if a flexible work proposal could have repercussions on coworkers, the law contemplates that the employee will take those potential effects into account, including, if necessary, discussing his or her proposal with coworkers and obtaining their feedback. ${ }^{246}$ Similarly, the employee is expected to structure and present his or her proposal so as to maximize the benefit to the employer where possible. $^{247}$

The Act requires an equal degree of thoughtfulness on the part of the employer. The employer may not reject a request without open-minded participation in a face-to-face meeting with the worker, ${ }^{248}$ and it may subsequently deny the request only for a legitimate and supportable business reason, which must be explained in writing. ${ }^{249}$ It is not enough for the employer simply to state that the request is costly or incompatible with its needs; government guidance suggests that an explanation for denying a request should be approximately two paragraphs long. ${ }^{250}$ The employer must be able to back up any business rationale with facts.

Given that there is no substantive right under the U.K. law, remedies and oversight are limited. However, the employee may file a complaint based on any failure to follow the procedure, in which case the tribunal can order the employer to reinstitute the process. ${ }^{251}$ In addition, a reviewing tribunal may make a limited review of the rationale for denying an application. It must defer to the business judgment of the employer, but it may find a violation where it can be shown that the employer relied on inaccurate facts or information in rendering the decision. ${ }^{252}$ Finally, an employee is protected against retaliation for seeking flexible work. In

${ }^{245}$ Employment Act, 2002, c. 22, § 47.

${ }^{246}$ See, e.g., RIGHT TO REQUEST, supra note 234, at 9 (providing a case study of a request for reduced hours scenario in which an employee reports in his application that he has discussed his preferred schedule with coworkers and that they support it).

${ }^{247}$ See, e.g., id. at 13 (providing a case study of a request for altered hours scenario in which an employee reports in her application that shifting her hours from morning to lunch time will maximize staffing during the busiest part of the work day).

${ }^{248}$ Both parties must come to the meeting "prepared to be flexible" and willing to discuss alternative arrangements besides the employee's request. Id. at 17 .

${ }^{249}$ Recognized reasons for rejecting a flexible work request are limited to additional cost, inability to reorganize staff or recruit additional staff, detrimental impact on quality, performance, or customer demand, insufficient work, or planned structural change. Employment Act, 2002, c. 22, § 47.

${ }^{250}$ RIGHT TO REQUEST, supra note 234, at 24.

251 Terms and Conditions of Employment, 2002, S.I. 2002/3207, ๆ 6 (U.K.).

${ }^{252}$ However, the explanation may be examined more closely in a case where the employee also alleges discrimination, for instance, on the basis of disparate impact (what the United Kingdom terms "indirect discrimination"). See RIGHT TO REQUEST, supra note 234 at $40-41$. 
the case of any violation, the tribunal may award the employee up to eight weeks pay subject to a statutory cap. ${ }^{253}$

Most importantly, research on the effects of the U.K. law has shown positive results. The creation of the law and the articulation of a "right" to request appear to have made a difference in the frequency with which employees make requests for flexible work. Twenty-eight percent of organizations reported an increase in requests compared to past years, which included not only requests from those eligible under the new law, but from other employees as well. ${ }^{254}$ More importantly, of those eligible employees submitting requests, seventy-five percent received full voluntary approval by the employer. ${ }^{255}$ Studies of similar European laws also show high rates of compliance. ${ }^{256}$ Finally, while employers are split over whether the right to request helps or hurts business, ninety percent of employers perceived compliance with the new law to be unproblematic ${ }^{257}$ Less than thirteen percent of U.K. employers reported that cost was an issue in implementing the right to request. ${ }^{258}$

While it is probably too soon to reach definitive conclusions about the success of the U.K. law, preliminary information about the British experience gives ample reason to believe that legislatively conferred procedural rights can be worthwhile. Among other things, such laws can create awareness among employees, encourage requests, lay the groundwork for cooperation between employees and employers, and in at least some cases result in jointly achieved, tailored accommodations for the benefit of caregivers. ${ }^{259}$

${ }^{253}$ Terms and Conditions of Employment, 2002, 77.

254 Jodie LeVin-EPSTEIN, CTr. FOR LAw \& Soc. Policy, How to Exercise FleXible WORK: TAKE STEPS WITH A "SOFT TOUCH" LAW 5 (2005), available at http:// www.clasp.org/publications/work_life_brf3.pdf.

${ }^{255} \mathrm{Id}$. at 4 . Another study found seven out of ten requests were fully approved, and one in ten partially approved. HEGEWISCH, supra note 235, at 2.

${ }^{256}$ A study of a similar German law concluded that nine out of ten requests were accepted by employers, while a study of the comparable Dutch law found that six out of ten were fully accepted and one out of ten partially accepted. HEGEWISCH, supra note 235, at 2.

${ }^{257} \mathrm{Id}$. at 5 .

${ }^{258} I d$. at 2.

259 Obviously there are differences between the United States and the United Kingdom that might affect societal receptiveness to comparable protective legislation and its ultimate effectiveness. For instance, by European Union ("E.U.") directive, part-time workers are entitled to parity in pay and access to benefits, and Europe obviously has a stronger regulatory culture with respect to labor issues generally. See LEVIN-EPSTEIN, supra note 254, at 6-7 (summarizing the minimum standards for paid and unpaid leave prescribed by U.K. and E.U. law). But the nature of the British proposal, with its absence of any substantive mandate, is consistent with the hands-off American approach to workplace regulation and certainly more deferential to business than other civil rights laws, like the ADA. Moreover, the absence of additional protections for American caregivers seems likely to affect the type of requests lodged more so than their frequency or acceptability. Thus, in the United States, where part-time employees often do not receive benefits, employees may request pro rata access to employer benefit plans as part of their 


\section{The Sociological Effects of Organizational Justice in the Workplace}

While the U.K. law offers an important case study of the potential effectiveness of an organizational justice approach to caregiver accommodation, social science literature offers a further empirical basis for supposing such an approach can achieve positive results. Research and anecdotal experience suggest that employers are predisposed to engage in accommodations when they are discoverable and mutually advantageous, that the existence of formal procedures can empower workers, and that interaction between employer and employee can help overcome stereotype and bias.

While data on the implementation of accommodations for the disabled are scarce, existing data contradict the assumption of discrimination scholarship that employers wish to avoid accommodating workers. Research gathered prior to the adoption of the ADA shows that even before legal mandates, some companies accommodated disabled employees voluntarily, finding it inexpensive and positive for workplace morale and efficiency. ${ }^{260}$ Current research shows that employers routinely provide accommodations to employees who do not meet the ADA's definition of disability. ${ }^{261}$ Moreover, the types of accommodations employers provide often go beyond what the ADA actually requires. The most transformative types of accommodations - and the ones most likely to be found unreasonable or incompatible with essential job functions by courts, such as job restructuring,

accommodation requests; if employers are not amenable to such proposals, we might expect workers concerned about benefits to seek smaller reductions in hours, or flexible hours, rather than part-time status.

Perhaps the more critical distinction between the U.K. and U.S. systems with respect to a procedural initiative is that employment claims in the U.K. are heard by specialized tribunals. In contrast, the task of reviewing the request and consideration process under a comparable American law would fall to federal judges with less expertise and heavy dockets. Cf. Bagenstos, Structural Turn, supra note 96 at 34 (raising questions about the competence and willingness of courts to review institutional practices in assessing substantive liability for structural discrimination). While this concern ought not preclude experimentation with procedural mandates, it does suggest that careful elaboration of the nature of the employer's obligation and scope of judicial review will be critical to the success of such an endeavor. A thorough evaluation of the various legal models of procedural compliance that could offer a baseline for such efforts, see note 145 supra, is beyond the scope of this Article.

${ }^{260}$ See Barbara A. Lee \& Karen A. Newman, Employer Responses to Disability: Preliminary Evidence and a Research Agenda, 8 EMP. RESPS. \& RTS. J. 209, 221 (1995) (finding that, out of a sample of fifty private sector companies in New Jersey who had accommodated at least one employee with a disability prior to the enactment of the ADA, ninety-two percent of employers said that their experience was successful).

${ }^{261}$ See Helen A. Schartz, et al., Workplace Accommodations: Empirical Study of Current Employees, 75 Miss. L.J. 917, 941-42 (2006) (finding in nationwide study of employers who contacted the Job Accommodation Network that forty-three percent of accommodated employees did not suffer a substantial limitation of a major life activity). 
working from home, and flexible hours-have been implemented by employers on a voluntary basis. ${ }^{262}$

The same thing is happening to some extent in the work/family context despite the absence of an affirmative mandate. Many employers already provide a limited amount of paid leave to workers taking parental leave or provide workers the option of using other forms of paid leave to cover FMLA leave. ${ }^{263}$ Some offer flexible scheduling arrangements or other accommodations that can help caregivers transition back to work following leave. ${ }^{264}$ One study found that small employers not subject to the FMLA voluntarily abided by its provisions, holding jobs open for twelve weeks, or more, for a variety of family-related reasons, including some not covered by federal law. ${ }^{265}$ In addition, widely publicized

${ }^{262}$ See Barbara Granger et al., Findings from a National Survey of Job Coaches and Job Developers About Job Accommodations Arranged Between Employers and People with Psychiatric Disabilities, 9 J. VoCATIONAL ReHAB. 235, 240 (1997) (citing employers' willingness to offer, among other accommodations, the option to work part-time hours, flexible work schedules, and adaptation of existing job descriptions); Lee \& Newman, supra note 260, at 218; Craig Zwerling et al., Workplace Accommodations for People with Disabilities: National Health Interview. Survey Disability Supplement, $45 \mathrm{~J}$. OCCUPATIONAL \& ENVTL. MED. 517, 520 (2003) (finding that part-time work and flexible scheduling are cited as the most commonly received accommodations). For an explanation of the economic incentives to employer accommodation in the disability context, see generally Seth D. Harris, Law, Economics and Accommodations in the Internal Labor Market, 10 U. PA. J. BUS. \& LAB LAW (forthcoming 2007-08), available at http:// papers.ssrn.com/sol3/cf_dev/AbsByAuth.cfm?per_id=111769.

263 See Heather Boushey, CTR. FOR ĖCON. \& POliCy Research, FaMilyFriendly Policies: Boosting Mothers' Wages 6-7 (2005) (finding that prior to the California program providing paid leave for workers caring for a new child or sick family member in 2002, data collected from 1996 and 2001 indicated $42.9 \%$ of mothers that took maternity leave received some pay from employers, either in the form of paid maternity leave or other paid leave, including sick leave, disability, and vacation); Eileen Appelbaum \& Ruth Milkman, Achieving A Workable Balance: New Jersey Employers' Experiences Managing Employee Leaves and Turnover, Center for Women and Work, School of Management and Labor Relations, Rutgers, The State University of New Jersey 5-6 (finding that about half of New Jersey employers interviewed offered paid parental or family leave and almost all offered other fringe benefits that could serve as sources of income during family-related leaves).

${ }^{264}$ See Kelly, supra note 2, at 30-35 (describing a variety of voluntary employer efforts to accommodate caregiving and their effectiveness); Jennifer E. Swanberg et al., $A$ Question of Justice: Disparities in Employees' Access to Flexible Schedule Arrangements, 26 J. FAM. ISSUES 866, 869-70 (2005) (finding studies of large and small employers show that sixty-eight percent of workplaces with one hundred or more employees and eighty percent of small businesses with fewer than fifty employees reported that at least some of their workforce has the ability to adjust their work hours, and that the proportion of fulltime workers with flexible schedules doubled between 1991 and 1997).

${ }^{265}$ See Appelbaum \& Milkman, supra note 268 at 8-10. 
initiatives within particular companies, such as Best Buy, ${ }^{266}$ Deloitte \& Touche ${ }^{267}$ and Fleet Bank, ${ }^{268}$ show an inclination on the part of at least some employers to make meaningful changes to their work structures to help all employees balance life needs. ${ }^{269}$ Thus, there is no reason to assume that employers will automatically deny proposed accommodations in the absence of a legal requirement, and to the extent that employers are willing to accommodate, an interactive process ensures that their voluntary initiatives actually serve the needs of those who require them.

A second important area of empirical research is the study of procedural justice and distributive justice perceptions. Research in organizational psychology has long suggested that employees who have a voice in organizational decisions are more likely to view their employer as fair. ${ }^{270}$ While initially this research theorized that the value in procedural justice lay in the assumption that fair process leads to distributionally fair outcomes, later research found that the perception of fairness was present even in cases with seemingly unfavorable outcomes. ${ }^{271}$ On one hand, this may be cause for concern. If employees perceive their workplace to be fair when it actually is not, there is a serious risk that employers will adopt procedures that merely perpetuate the status quo. ${ }^{272}$ However, there is another way

${ }^{266}$ See Jyoti Thottam, Reworking Work, TIME, July 25, 2005, at 50, 50-55 (discussing Best Buy's establishment of a "results-oriented work environment" at their Minneapolis headquarters where nearly half of the workforce chooses when and whether to come in to the office on a fluctuating basis).

${ }^{267}$ See Sturm, supra note 1, at 492 (discussing Deloitte \& Touche's "Women's Initiative" program under which the company created participatory task forces to determine the cause of a gender gap in promotion and turnover and implemented changes to address those underlying conditions, resulting in increased rates of advancement and reduced turnover for women employees).

${ }^{268}$ See Elaine St. James, More Employers Offer Flexible Work Policies, WASH. TIMES, Jan. 30, 2001, at E2 (discussing Fleet Financial Group's decision to offer every employee a flexible schedule after finding that managers with flexible schedules generate millions of dollars more in new business than their full-time counterparts).

${ }^{269}$ See Sue Shellenbarger, Employers Step Up Efforts to Lure Stay-at-Home Mothers Back to Work, WALL ST. J., Feb. 9, 2006, at D1 (describing employer family-friendly initiatives designed to help women return to the work force after taking time off to raise children).

${ }^{270}$ See N. Ramamoorthy \& P.C. Flood, Gender and Employee Attitudes: The Role of Organizational Justice Perceptions, 15 BRIT. J. MGMT. 247, 249-50 (2004) (summarizing studies that found increased employer communication about procedures and processes resulted in fewer employee perceptions of inequities).

${ }^{271} I d$. at 255 (finding that a "fair process of consistent enforcement of standards and the opportunity to resolve differences may result in more favorable perceptions of the outcome itself').

${ }^{272}$ See Phyllis A. Siegel et al., The Moderating Influence of Procedural Fairness on the Relationship Between Work-Life Conflict and Organizational Commitment, $90 \mathrm{~J}$. APPLIED PSYCHOL. 13, 20 (2005) (suggesting that employers may be able to avoid costly content-based work-life programs and still preserve employee commitment by exhibiting procedural faimess through such techniques as involving workers in discussions of workload and listening respectfully to their concerns about managing multiple demands). 
to interpret the data. Social science research shows that procedurally fair treatment of individuals within groups signals value to the group, enhancing self-esteem and instilling a sense of empowerment. ${ }^{273}$ This is critical with respect to employees who might not otherwise feel free to engage their employers informally. Studies suggest the benefits of voluntarily provided flexible scheduling programs fall primarily on white, professional workers; non-white workers in lower educational and earnings brackets reported less ability to access such opportunities. ${ }^{274}$ Transparent, consistent policies could be important to an employee in this category who does not have access to or comfort with the informal channels that privileged workers are capable of exploiting to obtain special work arrangements. ${ }^{275}$ Where procedures are formalized and equally available to all, an employee who was otherwise inhibited might be more likely to request and press for an accommodation.

The same research also offers hope that organizational justice exercises will foster positive group sentiment that could lessen the risk of resentment by nonaccommodated workers. One explanation for the fact that procedural justice leads to the perception of favorable results is that workers are less likely to fear exploitation where fair procedures are in place. ${ }^{276}$ Under those circumstances, employees are willing to trust that their employer's decisions are in the best interest of the collective whole; whereas absent fair process, employees are more likely to perceive favoritism and be motivated to maximize individual interests. ${ }^{277}$ Thus, accommodations of caregivers that stem from a formalized process may be less likely to occasion backlash from unencumbered workers.

Finally, there is reason to believe the mutual exposure occasioned by internal procedures can in some instances help break down implicit bias. Social scientists

273 See Karen A. Hegtvedt et al., The Social Context of Responses to Injustice: Considering the Indirect and Direct Effects of Group-Level Factors, 16 SOC. JUST. RES. 343, 348 (2003) (summarizing a study that found "fair treatment by group authorities conveys to individuals that they are valued members of the group, which, in turn, increases their self-esteem").

${ }^{274}$ See Lonnie Golden, The Flexibility Gap: Employee Access to Flexibility in Work Schedules, in FLEXIBILITY IN WORKPLACES: EFFECTS ON WORKERS, WORK ENVIRONMENT AND THE UNIONS 38 (Isik Urla Zeytinoglu ed., 2005); Swanberg et al., supra note 264, at 866.

${ }^{275}$ See Siegel et al., supra note 272 , at 14 (theorizing that fair internal procedures can lead employees to trust that organizational authorities will help them manage work-life conflict and to respond reasonably when such conflicts cause temporary periods of underperformance); $c f$. Elizabeth A. Hoffman, Law in the Workplace: Dispute Resolution in a Worker Cooperative: Formal Procedures and Procedural Justice, 39 LAW \& SoC'Y REV. 51, 73-77 (2005) (finding women preferred formal grievances systems more often than men because women lacked access to networks necessary to accomplish informal resolution).

${ }^{276}$ See Hoffman, supra note 275 , at $73-77$.
See id. 
have long known that consciously held beliefs are affected by context. ${ }^{278}$ For this reason, exposure to and interactions with persons of different backgrounds in the workplace can affect self-reported attitudes toward that group. ${ }^{279}$ More recent work suggests that contextual factors can also shape unconscious attitudes, including automatic racial and gender biases. ${ }^{280}$ Categorization experiments, for instance, show that exposing subjects to an African-American test administrator, or to wellknown African-American personalities, will produce results evaluating blacks as a group more positively than the results of a control group. ${ }^{281}$

A required interactive process between a manager and a non-traditional worker could serve as the stimulus that alters implicitly held negative beliefs. Social psychologists have theorized that stimuli presented to test subjects do not change fixed attitudes so much as they affect the immediate construction of those attitudes, which are built anew and in context whenever circumstances require their retrieval. ${ }^{282}$ Fixed beliefs, under this view, are not truly fixed, but the response to recurrent exposure to particular circumstances. This theory is consistent with the assumption of cognitive bias that repeated associations between the work environment and mainstream ideal workers shape employers' implicit assumptions about who is and is not a competent, reliable worker. If so, requiring an interactive process between management and employees in need of accommodation can potentially make a difference in tackling the problem of unconscious bias by offering a new situational context in which the decision maker's views about nontraditional workers can be reformed.

${ }^{278}$ See Jason P. Mitchell et al., Contextual Variations in Implicit Evaluation, $132 \mathrm{~J}$. EXPERIMENTAL PSYCHOL. 455, 456 (2003) (summarizing research indicating contextual factors can systematically shift self-reported attitudes and beliefs).

${ }^{279}$ See Adrienne Colella et al., Factors Affecting Coworkers' Procedural Justice Inferences of the Workplace Accommodations of Employees with Disabilities, 57 PERSONNEL PSYCHOL. 1, 12 (2004) (suggesting the more exposure coworkers have had to disabled workers, the more likely they are to assume that accommodations made by their employer are fair); Dean B. McFarlin et al., Integrating the Disabled into the Work Force: A Survey of Fortune 500 Company Attitudes and Practices, 4 EMP. RESPS. \& RTS. J. 107, 114-16 (1991) (finding in a pre-ADA study of Fortune 500 companies that employers with higher levels of exposure to the disabled were more likely to report positive views of disabled workers).

${ }^{280}$ See Jerry Kang, Trojan Horses of Race, 118 HARV. L. REV. 1489, 1505-06 (2005) (summarizing research indicating that schemas operate automatically without conscious intention and outside of our awareness); Mitchell et al., supra note 278, at 467.

${ }^{281}$ See Nilanjana Dasgupta \& Anthony G. Greenwald, On the Malleability of Automatic Attitudes: Combating Automatic Prejudice with Images of Admired and Disliked Individuals, 81 J. PERSONALITY \& SOC. PSYCHOL. 800, 800 (2001) (suggesting exposure to pictures of admired and disliked exemplars can reduce automatic preference for white over black Americans); Brian S. Lowery et al., Social Influence Effects on Automatic Racial Prejudice, 81 J. PersonAliTY \& SOC. PSYCHOL. 842, 842 (2001) (finding that European Americans exhibited less automatic prejudice in the presence of a black experimenter than a white experimenter).

${ }^{282}$ See Mitchell et al., supra note 278 , at 467-68. 


\section{Conclusion}

Initial attention by courts to the organizational practices of employers in some areas of discrimination law was not tied, at least initially, to broader movements in regulatory theory or empirical research. The Supreme Court's approach to vicarious liability in Ellerth ${ }^{283}$ and Faragher ${ }^{284}$ appears to have been cut from whole cloth. Yet, as this section has demonstrated, its approach dovetails with efforts of governance theorists to forge a friendlier approach to regulating private entities, one that paves a middle way between free-market principles and top-down government control. Indeed, Ellerth and Faragher heralded a wave of discrimination scholarship that has justified these decisions on theoretical grounds and made wider claims about the need to account for organizational actors and internal practices in developing a second-generation approach to workplace inequities. At the same time, actual experience, like the 2003 U.K. legislation on requesting flexible work, ${ }^{285}$ offers reason to believe that an organizational justice approach to regulating caregiver employment quality is not only theoretically justified but able to work on the ground. Preliminary results from that initiative, as well as anecdotal evidence from within the United States, demonstrate a proclivity among some employers to voluntarily accommodate workers. And finally, sociological research offers hope that workplace procedures can have positive effects on employer perceptions and employee self-esteem, both of which must occur for the goal of equal employment quality to be realized.

\section{QUESTIONS AND CONCLUSIONS}

This Article seeks an alternative path to redressing disparities between the employment quality of caregivers and mainstream workers, one that relies on procedural rights grounded in an organizational justice model of worker protection, rather than expanded substantive rights in the tradition of equal protection and accommodation mandates. Two pragmatic observations drive this move. First, the inherent limitations of an inflexible rule-based regime, coupled with the lack of political and social support for expanded substantive rights benefiting particular groups, make it unlikely that traditional approaches to redressing disparate employment quality will significantly erode the obstacles caregivers face at work. Second, achieving and sustaining a more inclusive workplace cannot result from external forces alone; success requires the support and leadership of organizations themselves. Therefore, one goal of any transformative agenda must be an environment of shared respect, trust, and deference between private actors, advocates for change, and of course individual workers.

${ }^{283}$ Burlington Indus. v. Ellerth, 524 U.S. 742 (1998).

${ }^{284}$ Faragher v. Boca Raton, 524 U.S. 775 (1998).

${ }^{285}$ See supra Part IV.B.1. 
Doubtlessly, the specific proposal advanced here is only a beginning. Many questions must be answered, and many criticisms addressed. Certainly some thinkers will find a procedural initiative inadequate, or warn that any process-based approach will be subverted by employers in service to their own ends. I do not claim that a mandated interactive process of the type that I envision will help every caregiver, nor deny that more aggressive approaches may be necessary in some cases. But such efforts are not mutually exclusive. There is no reason to reject an organizational justice approach to mainstreaming caregivers simply because it cannot transform every workplace. Rather we should capitalize on what can be accomplished through friendly regulation, while continuing the project of lobbying for increased substantive protections, recognizing that both approaches have their limitations and, further, that each is likely to be more effective in combination with the other. If an organizational justice approach succeeds in creating more inclusive cultures in some workplaces, one can expect that at least those employers may be more tolerant of substantive measures. Similarly, where expanded substantive rights are at stake, employers should be more willing to embrace procedures that will enable them to find the most manageable path to compliance and potentially reduce their risk of substantive liability.

More problematic is the risk of false compliance. If employers respond by establishing sham procedures that either deter or superficially appease their workers, then the current proposal may ultimately do more harm than good. While that risk should not be diminished, it does not call for a wholesale rejection of the organizational justice model and its potential benefits. Rather, the challenge is to develop sound mechanisms for evaluating employer behavior that will capture and deter bad actors as part of the broader organizational justice project. Indeed, a critical component of the current proposal is meaningful external review, both where procedural violations are alleged and where the burden of proof on related substantive claims may be affected. That review must include not only an objective assessment of employer behavior of the variety associated with the Ellerth/Faragher defense, but also actual consideration of employers' good faith. A fuller treatment of the meaning of that standard and courts' ability to apply it in individual cases must await a future project, yet it should be noted that judicial evaluation of good faith has a long history in both public and private law, and courts have already had much success in implementing such principles in the ADA interactive process context.

I also set aside for the moment the possibility of an organizational justice approach that reaches beyond particular categories of workers to enhance employee voice more generally. Surely there are non-caregivers who likewise require workplace accommodations and have limited or no substantive rights, and no doubt all workers desire and could benefit from greater say in employer practices. While I thoroughly support that vision, I believe that the targeted use of organizational justice principles to achieve a broader culture of sharing between workers and management is a separate project, and one that will face many challenges. Among other things, implementing the model in this way will require creative approaches to providing incentives for employer participation given the 
absence of obvious substantive tie-ins, like the FMLA and PDA, and certainly a thorough evaluation of the relationship of such a model to traditional labor law would be necessary. While such matters are beyond the scope of this Article, I am confident that successful implementation of the caregiving proposal described here can effect cultural changes in the workplace that inure to the benefit all employees and hope that my ideas can serve as a starting point for future discussions about how to achieve democratic participation by all classes of employees in all places of employment.

In conclusion, the incentivized organizational justice model advanced here seems a logical next step in the quest for caregiver parity at work. On a theoretical level, it avoids problematic reliance on notions of fault to capture bias and exclusion that occur unconsciously or without animus, instead reframing the inquiry in more relevant and less pejorative terms of employers' responsiveness to the needs of its non-traditional workers. On a pragmatic level, an organizational justice model avoids the pitfalls associated with equality and accommodation laws, provides a tool for achieving flexible and site-specific solutions, and likely enjoys wider social and political support than traditional rulemaking efforts. Finally, the ends as well as the means of this approach is a collaborative process between employer and employee that seeks to mainstream non-traditional workers. In this way, the organizational justice approach advanced here identifies and targets the "real" problem of second-generation workplace disparities-the fact that the historical exclusion and segregation of caregivers from and within market work has resulted in the perpetuation of workplace structures and latent stereotypes that continue to penalize these workers. By mandating employer/caregiver interaction and facilitating voluntary accommodation, the organizational justice approach offers the potential for enhanced communication, revitalized managerial practices, and true cultures of inclusion in our increasingly diverse work world. 